OPEN ACCESS

Edited by:

Vanessa F. Fonseca,

Center for Marine and Environmental

Sciences (MARE), Portugal

Reviewed by:

Cátia Esteves Da Silva,

Durham University, United Kingdom

Jiachen Sun,

Jinan University, China

*Correspondence:

Juan José Alava

j.alava@oceans.ubc.ca;

jalavasa@sfu.ca

${ }^{\dagger}$ Deceased (November 19, 2019)

Specialty section:

This article was submitted to

Marine Pollution,

a section of the journal

Frontiers in Marine Science

Received: 30 December 2019

Accepted: 14 February 2020

Published: 20 March 2020

Citation:

Alava JJ, Calle P, Tirapé A, Biedenbach G, Alvarado Cadena O,

Maruya K, Lao W, Aguirre W,

Jiménez PJ, Domínguez GA

Bossart GD and Fair PA (2020)

Persistent Organic Pollutants and Mercury in Genetically Identified

Inner Estuary Bottlenose Dolphin (Tursiops truncatus) Residents of the

Guayaquil Gulf, Ecuador: Ecotoxicological Science in Support

of Pollutant Management

and Cetacean Conservation.

Front. Mar. Sci. 7:122.

doi: 10.3389/fmars.2020.00122

\section{Persistent Organic Pollutants and} Mercury in Genetically Identified Inner Estuary Bottlenose Dolphin (Tursiops truncatus) Residents of the Guayaquil Gulf, Ecuador: Ecotoxicological Science in Support of Pollutant Management and Cetacean Conservation

\author{
Juan José Alava ${ }^{1,2,3 *}$, Paola Calle ${ }^{4}$, Ana Tirapé4, George Biedenbach ${ }^{5}$ \\ Omar Alvarado Cadena ${ }^{4}$, Keith Maruya ${ }^{6}$, Wenjian Lao ${ }^{6}$, Windsor Aguirre ${ }^{7}$, \\ Pedro J. Jiménez ${ }^{3}$, Gustavo A. Domínguez ${ }^{4}$, Gregory D. Bossart ${ }^{5 t}$ and Patricia A. Fair ${ }^{8,9}$ \\ ${ }^{1}$ Institute for the Oceans and Fisheries, The University of British Columbia, Vancouver, BC, Canada, ${ }^{2}$ School of Resources \\ and Environmental Management, Simon Fraser University, Burnaby, BC, Canada, ${ }^{3}$ Fundación Ecuatoriana para el Estudio \\ de Mamiferos Marinos (FEMM), Guayaquil, Ecuador, ${ }^{4}$ Laboratorio de Investigaciones Toxicológicas y Salud Ambiental, \\ Facultad de Ciencias de la Vida, Escuela Superior Politécnica del Litoral, ESPOL, ESPOL Polytechnic University, Guayaquil, \\ Ecuador, ${ }^{5}$ Georgia Aquarium, Atlanta, GA, United States, ${ }^{6}$ Southern California Coastal Water Research Project, Costa \\ Mesa, CA, United States, ${ }^{7}$ Department of Biological Sciences, DePaul University, Chicago, IL, United States, ${ }^{8}$ South \\ Carolina Aquarium, Charleston, SC, United States, ${ }^{9}$ Department of Public Health Sciences, Medical University of South \\ Carolina, Charleston, SC, United States
}

The bottlenose dolphin is one of the most common cetaceans found in the coastal waters, estuaries, and mangroves of Ecuador. However, its population size is gradually declining in the Gulf of Guayaquil, and anthropogenic factors including habitat degradation, uncontrolled dolphin watching, dredging activities, increasing maritime traffic, underwater noise, bycatch, and marine pollution have been implicated in their decline. Very little is known about contamination by persistent organic pollutants (POPs) and mercury in bottlenose dolphins from the Pacific coast of South America. To address this research gap, the first assessment of total mercury (THg) and POPs, including polychlorinated biphenyls (PCBs), organochlorine pesticides (OCPs), and polybrominated diphenyl ethers (PBDEs), in free-ranging bottlenose dolphins in mangroves (El Morro Mangrove Wildlife Refuge) of the Gulf of Guayaquil, was conducted in Ecuador in 2018. Dolphin samples (i.e., skin and blubber; $n=9$ ), were obtained using dart biopsy field methods for contaminant analysis. POP concentrations ranged from 0.56 to $13.0 \mathrm{mg} / \mathrm{kg}$ in lipid weight, while THg ranged from 1.92 to $3.63 \mathrm{mg} / \mathrm{kg}$ in dry weight. The predominant POPs were OCPs (50\% of $\Sigma$ POP), followed by PCBs (46\%) and PBDEs (6.0\%); particularly, $p, p^{\prime}-\mathrm{DDE}$, the main DDT metabolite and a potent antiandrogenic, accounting for $42 \%$ of $\Sigma$ POP, ranging from 0.12 to $\sim 7.0 \mathrm{mg} / \mathrm{kg} \mathrm{lw}$, followed by PCB 153 (8.0\%) and PCB 180 (5.0\%). PBDE 47 accounted for $2.0 \%$ of $\Sigma$ POP. While the $\mathrm{POP}$ concentrations are lower than those found in dolphins from many other regions 
of the world, some of the THg concentrations are within the concentration range found in dolphins from the southeastern coast of the United States. The ecotoxicological risk assessment showed that some of the sampled dolphins are exposed to immunotoxic and endocrine disruption effects by POPs and mercury. The low genetic diversity of this distinctive dolphin population, likely exhibiting genetic isolation and a unique evolutionary heritage, could be lost if the population continues to decline in the face of anthropogenic threats, including chemical pollution. Our finding shows that bottlenose dolphins in coastal Ecuador are exposed to environmental contaminants and can be used as sentinel species for ecosystem health to monitor pollution in the region and to support ecotoxicological risk assessment and regional pollutant management.

Keywords: contaminants, POPs, organic mercury, marine mammals, toxicological risk assessment, mangroves, Gulf of Guayaquil, South America

\section{INTRODUCTION}

Global contamination of the oceans and coastal-marine regions by legacy and emerging persistent organic pollutants (POPs) and mercury continues to be one of the top critical threats, as these contaminants are pervasive in the ocean environment, detected at fairly high concentrations in many marine species, capable of causing health effects, and driven by the longrange atmospheric transport in an era of global change (Alava et al., 2017a). Despite the international policy efforts of the Stockholm Convention on POPs (UNEP, 2002) and Minamata Convention on Mercury (UNEP, 2016) to control, mitigate, and eliminate their sources and contamination, these pollutants are still found in the global marine environment at unprecedented levels.

Persistent organic pollutants bioaccumulate in aquatic organisms and biomagnify in marine mammalian foodwebs (Kelly et al., 2007, 2009; Gobas and Arnot, 2010; Alava and Gobas, 2012; Cullon et al., 2012), reaching exposure concentrations above threshold health effect levels in some populations of apex predators, including marine mammals (e.g., Ross et al., 2000; Hall et al., 2005; Hickie et al., 2007, 2013; Jepson et al., 2016; Desforges et al., 2018). Several toxicological effects, for example, have been accredited to polychlorinated biphenyls (PCBs) in marine mammals, including molecular and cellular alterations leading to immunotoxicity, endocrine disruption, and reproductive impairment (Addison, 1989; Brouwer et al., 1989; Lahvis et al., 1995; Ross P. et al., 1996; Ross P. S. et al., 1996; Guise, 1998; Ylitalo et al., 2005; Tabuchi et al., 2006; Letcher et al., 2010; Mos et al., 2010; Bossart, 2011; Buckman et al., 2011; Desforges et al., 2016; Peñín et al., 2018). Both immunotoxicological and endocrine disruption effects by POPs (i.e., PCBs) are likely to be the most detrimental modes of toxic action in cetaceans, with possible indirect consequences at the population level (Hall et al., 2005; Hickie et al., 2007; Jepson et al., 2016; Desforges et al., 2018).

Similarly, mercury, in particular methylmercury ( $\mathrm{MeHg}$ ), is highly neurotoxic and bioaccumulates and biomagnifies in marine foodwebs almost entirely via dietary ingestion or uptake, attaining the highest concentrations in fish and organisms at the top of the foodweb (Scheuhammer et al., 2007, 2015;
Wiener et al., 2007; Sandheinrich and Wiener, 2011; Kehrig et al., 2013, 2017; Lavoie et al., 2013; Fort et al., 2015; Jonsson et al., 2017). Methylmercury can cause toxicity even at low concentrations (Dietz et al., 2013). Immunotoxicity, neurotoxicity, nephrotoxicity, and genotoxic effects of mercury in cetacean species, have been documented (Desforges et al., 2016; Kershaw and Hall, 2019). Specifically, mercury exposure in marine mammals (e.g., cetaceans) has been reported to affect the systemic suppression of immune function (i.e., suppression of lymphocyte proliferation and phagocytosis activity) (Desforges et al., 2016).

Among the marine mammal species used as indicators of contamination, the bottlenose dolphin (Tursiops truncatus) serves as a sentinel species to monitor the health and pollution of marine and coastal-estuarine environments due to its long life span, high trophic level in the marine food web and capacity to bioaccumulate environmental pollutants such as POPs and mercury (Wells et al., 2004; Fair, 2006; Stavros et al., 2007; Reif et al., 2008; Fair et al., 2010; Bossart, 2011). A myriad of studies on both emerging and legacy chemicals pollutants have been documented for this species in North America (Wells et al., 2005; Fair et al., 2007, 2009, 2010, 2013; Stavros et al., 2007, 2008; Reif et al., 2008; Yordy et al., 2010). However, very little is known concerning contamination by POPs and mercury in bottlenose dolphins and other marine mammal species from the Southeastern Tropical Pacific and the west coast of South America, except for the pioneering research on POPs in endemic pinnipeds from the Galapagos Islands, i.e., Galapagos sea lions (Zalophus wollebaeki) and Galapagos fur seals (Arctocephalus galapagoensis) (Alava et al., 2009, 2011, 2017b; Alava and Gobas, 2012; Alava and Ross, 2018), and the first assessment of POPs in Chilean blue whales (Balaenoptera musculus) from Isla de Chiloé, southern Chile (Muñoz-Arnanz et al., 2019). Generally, most studies on chemical contaminants (e.g., POPs, mercury) in Latin America have focused on small cetacean species from the Atlantic coast of South America, mainly along coastal Brazil (Yogui and Sericano, 2009; Alonso et al., 2010, 2012, 2015; Bisi et al., 2012; Santos-Neto et al., 2014; Lavandier et al., 2015, 2016, 2019; Baptista et al., 2016; Kehrig et al., 2016, 2017), and the southern marine-coastal regions of Chile and Argentina (Gerpe et al., 2002; Cáceres-Saez et al., 2015, 2018; Durante et al., 2016). 
In Ecuador, the bottlenose dolphin is an emblematic species for coastal-marine conservation. As an apex predator, its key role for the functioning, maintenance, and resilience of coastal mangrove ecosystems is of paramount importance (Jiménez and Alava, 2014; Alava et al., 2019). Of particular interest is the conservation status of the coastal ecotype and year-round resident population from the El Morro Mangrove Wildlife Refuge, located in the Guayaquil Gulf (Ecuador). Photoidentification studies since 2005, and population size estimates indicate a gradual decrease in the population of bottlenose dolphin in this wildlife refuge (Jiménez and Alava, 2014; Félix et al., 2017). While a population size (mean \pm SD) of $44 \pm 7.0$ photo-identified dolphins, ranging from 37 to 55 individuals, was estimated from 2001 to 2013 in El Morro Mangrove Wildlife Refuge (Jiménez and Alava, 2014), a recent abundance estimation of dolphins yielded 43 animals (95\% CI 37-49) in Posorja waters (Félix et al., 2017). The causes of this decline are not sufficiently evaluated, but anthropogenic factors such as degradation of the natural habitat, human activities linked to the illegal observation of dolphins, maritime traffic, marine sediments dredging, incidental catches, and direct hunting associated with artisanal fishing and environmental pollution can act as multi-anthropogenic and cumulative impacts to influence this decline (Jiménez et al., 2011, 2018; Jiménez and Alava, 2014, 2015; Alava and Ross, 2018; Alava et al., 2019). This cetacean is considered a "Vulnerable (VU)" species according to the official Red Book of the Mammals of Ecuador (Jiménez et al., 2011).

The coastal bottlenose dolphin, as a residing species and apex predator of the Gulf of Guayaquil Estuary, is considered a coastal sentinel (i.e., "the canary in the coal mine") to biomonitor and assess marine pollution risks and contaminant bioaccumulation in the region (Jiménez and Alava, 2014; Alava et al., 2019). In this context, the El Morro Refuge and the surrounding region (e.g., Morro Channel and Posorja Harbor) in the Gulf of Guayaquil (Ecuador) offer ideal conditions to measure POPs and mercury to evaluate the anthropogenic impacts on the ecosystem and the dolphins. This is important as the Gulf of Guayaquil is the one of the most productive bioregions, harboring the largest estuary and mangrove area (i.e., Gulf of Guayaquil Estuary) along the Pacific coast of South America (Twilley et al., 2001; Carvajal and Alava, 2007). However, the Gulf of Guayaquil Estuary is highly impacted by anthropogenic activities and changes in land use, with agriculture, aquaculture, industrial development, and urban sprawl being the main stressors at the regional level (Twilley et al., 2001; Borbor-Cordova et al., 2006; Carvajal and Alava, 2007; Calle et al., 2018).

Chemical pollution is an environmental problem of ongoing concern in the Gulf of Guayaquil due to POPs (e.g., dichloro-diphenyl-trichloroethanes, DDT), current used pesticides, hydrocarbons, pharmaceuticals and personal care products (PPCPs), butyltin (BT) compounds, and heavy metal contamination (Montaño and Resabala, 2005; Calle and Alava, 2009; Castro et al., 2012; Calle et al., 2013; Fernández-Cadena et al., 2014; Jiménez and Alava, 2014). For instance, DDT contamination was reported in sediment ( $1.36 \mu \mathrm{g} / \mathrm{kg}$ wet weight) and aquatic organisms $(2.87 \mu \mathrm{g} / \mathrm{kg}$ wet weight) from the Taura River Basin, a tributary of the Guayas River in the Gulf of
Guayaquil (Montaño and Resabala, 2005). Elevated mercury concentrations were also detected in estuarine sediments and aquatic organisms (i.e., mangrove mussels) from mangrove habitats, exceeding mercury sediment quality guidelines and toxic health effect thresholds (Calle et al., 2018).

Developing an understanding of how environmental chemicals may impact dolphins in coastal Ecuador is essential to enhance the conservation of bottlenose dolphins. One of the main research gaps identified for the conservation of bottlenose dolphin populations in Ecuador is the ecotoxicology of this region and monitoring of POPs and mercury in top predators such as dolphins (Jiménez and Alava, 2014; Alava and Ross, 2018; Alava et al., 2019). To address the lack of baseline contaminant data and ecotoxicological research in cetacean species of coastal Ecuador, this study uses the bottlenose dolphin as "canaries in the coal mine" to characterize environmental contaminant exposure, representing the first assessment of chemical contamination in a small cetacean species in the Pacific coast of South America. By assessing the environmental and anthropogenic factors affecting dolphins, this research supports management efforts for bottlenose dolphin conservation and its population recovery in coastal Ecuador.

\section{MATERIALS AND METHODS}

\section{Study Area}

The El Morro Mangrove Wildlife Refuge (REVISEM hereafter) is located $\left(2^{\circ} \mathrm{S}, 80^{\circ} \mathrm{W}\right)$ within the remaining riverine and estuarine mangroves close to the El Morro Channel, northwest of Puna Island, in the Gulf of Guayaquil $\left(3^{\circ} \mathrm{S} 80^{\circ} \mathrm{W}\right.$, Figure 1). REVISEM is a mangrove reserve belonging to the National System of Protected Areas and comprises 1,304 ha of mangrove forests, 700 ha of mudflats and 8,000 ha of surface water area; near the El Morro Refuge, there is an important fishing landing and trading port, Posorja harbor $\left(2^{\circ} 42^{\prime} \mathrm{S}, 80^{\circ} 14^{\prime} \mathrm{W}\right)$, where sampling was also deployed in surrounding waters (Figure 1 and Supplementary Figure S1).

\section{Sample Collection: Field Methods and Dart Biopsy Sampling}

A small sample of skin and blubber tissue $(<1.5 \mathrm{~cm}$ approximately) was collected using a dart biopsy technique. Dart biopsy sampling was conducted with a crossbow system (Crossbow Barnett, BCR Recurve Crossbow) equipped with a long $30 \mathrm{~mm}$ BSA Huntsman dot sight (BSA Huntsman $30 \mathrm{~mm}$ RGB dot sight) and equipped with special biopsy darts (Ceta-Dart using an Easton aluminum/carbon composite spring bolt shaft 3-71/300, equipped with removable and reusable stainless-steel M-11 cutting tips (11 mm in diameter). A stopper is used to prevent the dart from penetrating past the blubber. The biopsy collecting head was disinfected between and prior to each use; each tip was scrubbed, soaked in a chlorhexidine solution, solvent-rinsed, and then rinsed with distilled water. The equipment was used by a trained and experienced biologist. Samples were collected with the Barnett crossbow approximately $0.75 \mathrm{~m}$ above the water surface of a $7 \mathrm{~m}$-length fiberglass 

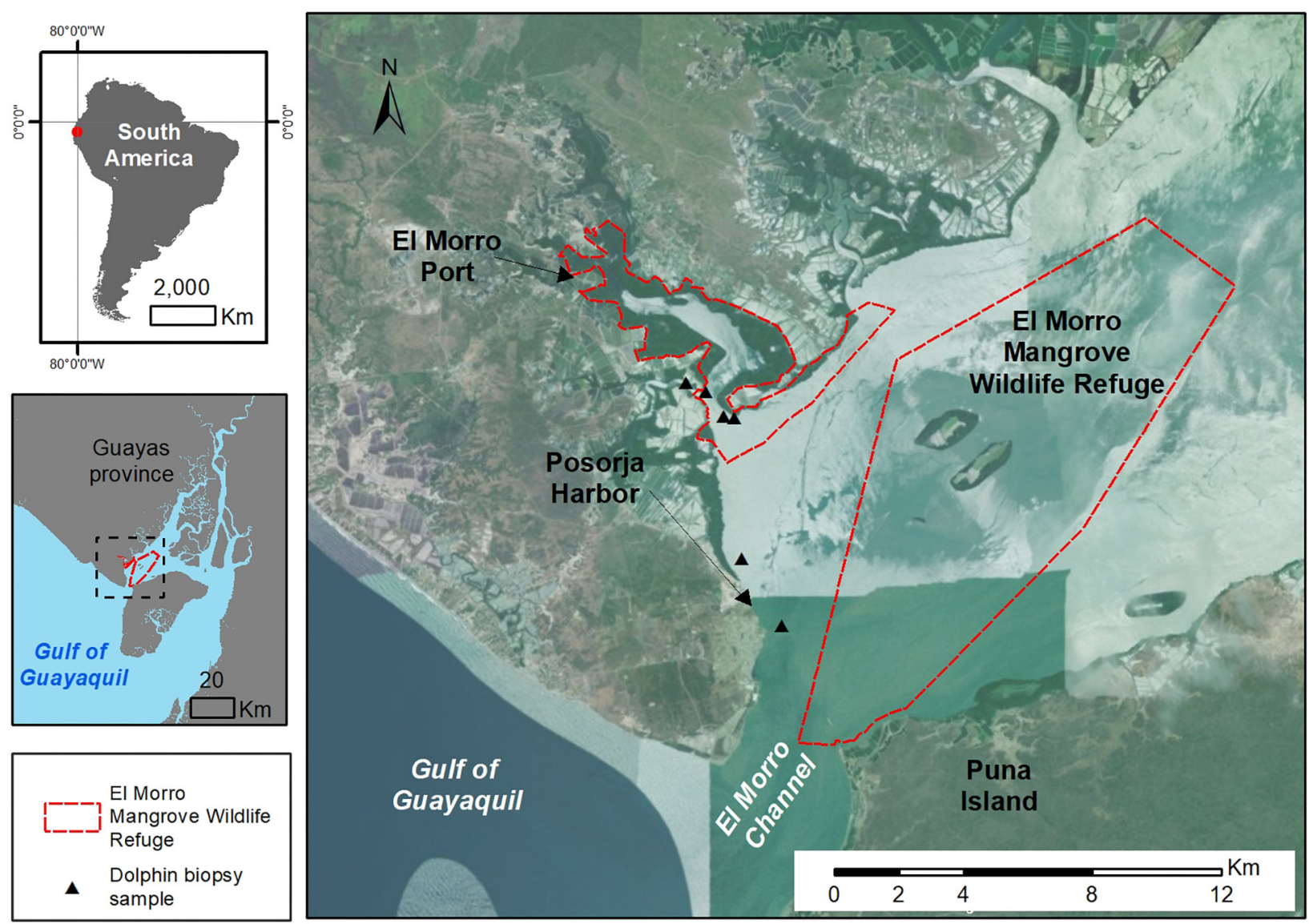

FIGURE 1 | Geographical location of El Morro Mangrove Wildlife Refuge (REVISEM) and surrounding areas (Posorja Harbor, El Morro Channel) in the Estuary of the Gulf of Guayaquil, Ecuador. The map illustrates the study area for biopsy sampling sites (triangles) in REVISEM and Posorja Harbor waters. Mangrove forests and urbanized and rural areas are also shown.

boat with outboard motor. Only individuals 2 years of age or older were biopsied based on the size of the dolphin and maternal dependence. Adult animals were sampled when they were alone and/or separated from the group at 4-6 m (i.e., based on the size of the dolphin and maternal dependence, which is evaluated in the field by the trained expert using the crossbow). Mothers with calves under 2 years of age and animals with apparently compromised health conditions (e.g., deformities, open lesions, signs of disease) were not sampled. The field methodology was adapted from the standard methodology used in similar studies throughout the world (see Barrett-Lennard et al., 1996; Krützen et al., 2002; Fair et al., 2003; Parsons et al., 2003; Jefferson and Hung, 2008; Kiszka et al., 2010; Tezanos-Pinto and Baker, 2012; Fruet et al., 2017). Dart biopsy sampling is a well-established field method routinely used with free-ranging cetaceans (Whitehead et al., 1990; Barrett-Lennard et al., 1996; Weller et al., 1997; Fair et al., 2003; Jefferson and Hung, 2008; Fruet et al., 2017). Dart biopsy procedures employed in this study were designed to minimize discomfort and risk to the animals of the small population inhabiting the mangrove estuarine ecosystem of the REVISEM. The safety protocol during biopsy sampling in the field followed the criteria considered during the sampling based on Wenzel et al. (2010).

Over the course of the field dart-biopsy sampling, 24 shots were deployed in the study area, including REVISEMN and Posorja harbor waters (Figure 1 and Supplementary Figure S1). The dart shooting distance ranged from a minimum distance of $4 \mathrm{~m}$ and maximum of $7.5 \mathrm{~m}$, averaging $5.1 \mathrm{~m}$. After retrieving the floating dart, the skin/blubber tissue $(1 \mathrm{~cm}$ in diameter $\times 1.5-$ $2 \mathrm{~cm}$ in depth and between 0.5 and $1.0 \mathrm{~g}$ in weight) was removed from the sampling head using solvent-cleaned forceps and a scalpel, separated, and placed in a liquid nitrogen container for genetic and contaminant analysis. A total of 12 clean hits with nine full dolphin samples (i.e., blubber and skin), constituting a $75 \%$ full sample rate (or $25 \%$ failure rate), and two skin only samples were collected. There were two dolphins sampled twice within the nine full samples, thus the sampling effort rendered full samples from a total of seven different individuals and full and partial samples from nine different individuals. Once the biopsy was recovered with the sample of tissues (skin and blubber), the skin was separated from the blubber with sterilized and clean scissors for analysis of total mercury (i.e., 2/3 skin sample) and genetics (1/3 of the skin sample) and all the blubber 
was used for POPs analysis. Table 1 shows the field data on sampled dolphins.

\section{Genetic Analysis for Haplotypes and Sex Determination}

To verify that the dolphins sampled were genetically consistent with the inner Gulf of Guayaquil estuary resident dolphin population (Bayas-Rea et al., 2018), DNA was extracted from skin tissue samples and a fragment of the mitochondrial control region was PCR amplified and sequenced. The control region was selected because it is the fastest evolving region of the mitochondrial genome and has been extensively used in population genetic analyses (e.g., Palumbi, 1996; Aguirre et al., 2013) including in cetaceans (e.g., Bayas-Rea et al., 2018). Gulf of Guayaquil bottlenose dolphin populations differ from populations in other geographic areas for this gene, as do inner and outer estuary populations in the Gulf of Guayaquil (Bayas-Rea et al., 2018). Skin tissue samples were stored in a $-80^{\circ} \mathrm{C}$ freezer until DNA purification. DNA was extracted using GeneJET genomic DNA purification kit from Thermo Scientific following the manufacturer's instructions. Purified DNA was quantified using a Nanodrop spectrophotometer and stored at $-20^{\circ} \mathrm{C}$ for use.

Two overlapping fragments of the mitochondrial control region were PCR amplified on a miniPCR ${ }^{\mathrm{TM}}$ mini16 thermal cycler using the primers dLp1.5t-pro (5'-TCACCCAAAGCTGRARTTCTA- $\left.3^{\prime}\right)$ and dlp5 (5'CCATCGWGATGTCTTATTTAAGRGGAA-3'), which yielded a PCR product approximately 550bp in length, and dLp1.5tpro and dLp8G (5'-GGAGTACTATGTCCTGTAACCA-3'), which yielded a PCR product approximately $800 \mathrm{bp}$ in length (Bayas-Rea et al., 2018). PCR reactions were carried out in $40 \mu \mathrm{L}$ volumes consisting of $1 \mathrm{X}$ PCR buffer (Omega Bio-Tek), 2X BSA (bovine serum albumin), $3.5 \mathrm{mM} \mathrm{MgCl}, 0.25 \mathrm{mM}$ dNTP (Omega Bio-Tek), $0.35 \mu \mathrm{M}$ primers, 1.5 units of Taq
DNA polymerase (Omega Bio-Tek), and approximately $100 \mathrm{ng}$ of template DNA. Cycling conditions consisted of a $94^{\circ} \mathrm{C}$ initial denaturation for $120 \mathrm{~s}, 35$ cycles of $94^{\circ} \mathrm{C}$ for $30 \mathrm{~s}, 55^{\circ} \mathrm{C}$ for $60 \mathrm{~s}$, and $72^{\circ} \mathrm{C}$ for $60 \mathrm{~s}$, followed by a final extension of $72^{\circ} \mathrm{C}$ for $420 \mathrm{~s}$. Successful amplification was verified by running a portion of the PCR products on a $1.5 \%$ agarose gel. Amplification of the 800bp fragment resulted in some unspecific amplification so the PCR product was cut from the agarose gel and purified using a QIAquick gel extraction kit (QIAGEN) following the manufacturer's instructions. PCR products for direct sequencing were cleaned using ExoSAP-IT ${ }^{\mathrm{TM}}$ (Thermo Fisher Scientific) and forward and reverse strands were sequenced for each fragment on an Applied Biosystems 3730 DNA Analyzer. Chromatograms were edited and aligned in Geneious Prime 2019 (Biomatters Ltd.). The alignment was conducted using the ClustalW 2.1 and manually inspected for errors. The two control region fragments were compared to check for sequencing errors. The final mtDNA control region sequence fragments were cut to $392 \mathrm{bp}$ in length to assign individuals to the haplotypes identified by Bayas-Rea et al. (2018) and determine whether the individuals sampled in this study are genetically consistent with inner estuary residents (GenBank Accession \# MT005757-MT005769). The number and frequency of distinct haplotypes was counted and haplotype diversity, $\mathrm{Hd}$, was calculated as $\mathrm{N}\left(1-\mathrm{p}_{\mathrm{i}}^{2}\right)^{*}(\mathrm{~N}-1)^{-1}$, where $\mathrm{p}_{\mathrm{i}}$ is the frequency of the $i$ th haplotype and $\mathrm{N}$ is the number of individuals in the sample (Nei, 1987).

Because male and female bottlenose dolphins can differ in their behavior, movement patterns, and susceptibility to contaminants, genetic markers from the sex chromosomes were used to identify the sex of the specimens sampled following Rosel (2003). Briefly, the primers TtSRYR (5'ACCGGCTTTCCATTCGTGAACG-3') and PMSRYF (5'-CATTGTGTGGTCTCGTGATC-3') were used to amplify the SRY gene and the primers ZFX0582F (5'ATAGGTCTGCAGACTCTTCTA-3') and ZFX0923R (5'-AGAATATGGCGACTTAGAACG-3') were used to amplify

TABLE 1 | Field data for dart biopsy sampling of bottlenose dolphin in the El Morro Mangrove Wildlife Refuge (REVISEM) and Posorja Harbor waters during May 2018.

\begin{tabular}{|c|c|c|c|c|c|c|c|c|}
\hline \multirow{2}{*}{$\begin{array}{l}\text { Date } \\
\text { May } 14,2018\end{array}$} & \multicolumn{2}{|c|}{ Geographical coordinates } & \multirow{2}{*}{$\begin{array}{l}\text { Sample no. } \\
\text { EDM-1-18 }\end{array}$} & \multirow{2}{*}{$\begin{array}{c}\text { Blubber } \\
\text { N/A }\end{array}$} & \multirow{2}{*}{$\begin{array}{l}\text { Skin } \\
\text { Yes }\end{array}$} & \multirow{2}{*}{$\begin{array}{c}\text { Field evaluation size class } \\
\text { Adult }\end{array}$} & \multirow{2}{*}{$\begin{array}{l}\text { Sex* } \\
\text { Male }\end{array}$} & \multirow{2}{*}{$\begin{array}{c}\text { Sample size } \\
\text { Partial }\end{array}$} \\
\hline & $2^{\circ} 38.762^{\prime} \mathrm{S}$ & $80^{\circ} 15.247^{\prime} \mathrm{W}$ & & & & & & \\
\hline May 14, 2018 & $2^{\circ} 34.344^{\prime} \mathrm{S}$ & $80^{\circ} 15.125^{\prime} \mathrm{W}$ & EDM-2-18 & N/A & Yes & Adult & Male & Partial \\
\hline May 16, 2018 & $2^{\circ} 38.384^{\prime} \mathrm{S}$ & $80^{\circ} 15.473^{\prime} \mathrm{W}$ & EDM-3-18 & $\mathrm{N} / \mathrm{A}$ & Yes & Adult & Female & Partial \\
\hline May 16, 2018 & $2^{\circ} 38.384^{\prime} \mathrm{S}$ & $80^{\circ} 15.473^{\prime} \mathrm{W}$ & EDM-4-18** & Yes & Yes & Subadult & Female & Full \\
\hline May 16, 2018 & $2^{\circ} 38.820^{\prime} \mathrm{S}$ & $80^{\circ} 15.000^{\prime} \mathrm{W}$ & EDM-5-18 & Yes & Yes & Adult & Male & Full \\
\hline May 16, 2018 & $2^{\circ} 38.793^{\prime} \mathrm{S}$ & $80^{\circ} 15.173^{\prime} \mathrm{W}$ & EDM-6-18 & Yes & Yes & Adult & Female & Full \\
\hline May 17, 2018 & $2^{\circ} 38.240^{\prime} \mathrm{S}$ & $80^{\circ} 15.800^{\prime} \mathrm{W}$ & EDM-7-18 & Yes & Yes & Adult & Male & Small \\
\hline May 18, 2018 & $2^{\circ} 63.967^{\prime} \mathrm{S}$ & $80^{\circ} 25.461^{\prime} \mathrm{W}$ & EDM-8-18** & $N / A$ & Yes & Subadult & Female & Partial \\
\hline May 18, 2018 & $2^{\circ} 63.064^{\prime} \mathrm{S}$ & $80^{\circ} 25.251^{\prime} \mathrm{W}$ & EDM-9-18 & Yes & Yes & Subadult & Female & Full \\
\hline May 21, 2018 & $2^{\circ} 41.187^{\prime} \mathrm{S}$ & $80^{\circ} 14.867^{\prime} \mathrm{W}$ & EDM-10-18 & Yes & Yes & Adult & Female & Full \\
\hline May 21, 2018 & $2^{\circ} 42.312^{\prime} \mathrm{S}$ & $80^{\circ} 14.207^{\prime} \mathrm{W}$ & EDM-11-18 & Yes & Yes & Adult & Male & Full \\
\hline May 21, 2018 & $2^{\circ} 67.113^{\prime} \mathrm{S}$ & $80^{\circ} 25.219^{\prime} \mathrm{W}$ & EDM-12-18 & Yes & Yes & Adult & Male & Full \\
\hline May 21, 2018 & $2^{\circ} 67.000^{\prime} \mathrm{S}$ & $80^{\circ} 24.877^{\prime} \mathrm{W}$ & EDM-13-18 & Yes & Yes & Adult & Male & Full \\
\hline
\end{tabular}

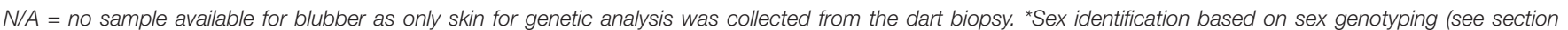

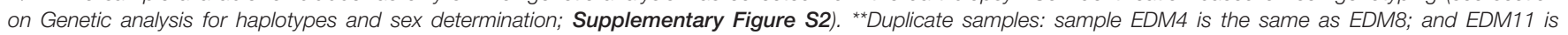
the same as EDM13. 
the ZFX gene. Males produce two bands that are 382 and 339 bp in length while females produce a single 382 bp band (Supplementary Figure S2). PCR amplification was conducted on a miniPCR ${ }^{\mathrm{TM}}$ minil 6 thermal cycler, with cycling conditions consisting of a $95^{\circ} \mathrm{C}$ initial denaturation for $120 \mathrm{~s}, 35$ cycles of $94^{\circ} \mathrm{C}$ for $30 \mathrm{~s}, 51^{\circ} \mathrm{C}$ for $45 \mathrm{~s}$, and $72^{\circ} \mathrm{C}$ for $45 \mathrm{~s}$, followed by a final extension of $72^{\circ} \mathrm{C}$ for $420 \mathrm{~s}$. PCR reactions were carried out in $40 \mu \mathrm{L}$ volumes with the reagent concentrations following those used for the control region amplification. PCR products were run on a $3 \%$ agarose gel until band separation was clearly visible in male specimens. Unfortunately, it was apparent that there was some unspecific amplification when the PCR products were run on the agarose gel. To verify that sex was scored correctly, the putative bands corresponding to the ZFX and SRY genes in a specimen identified as male were cut from the agarose gel, purified using a QIAquick gel extraction kit (QIAGEN) following the manufacturer's instructions, and then sequenced on an Applied Biosystems 3730 DNA Analyzer (GenBank Accession \# MT005756).

\section{POP Analysis}

Blubber samples were analyzed with standard solutions containing 19 organochlorine pesticides (OCPs), 43 polychlorinated biphenyl congeners (PCBs), and 13 brominated diphenyl ethers (BDEs) as target analytes (see Supplementary Table S1); as well as recovery surrogates 4, $44^{\prime}$-dibromooctafluorobiphenyl (DBOFB), $2,2^{\prime}, 3,3^{\prime}, 4,5,5^{\prime}$-heptabromobiphenyl ether (BDE-172); and $2,2^{\prime}, 3,3^{\prime}, 4,5,5^{\prime}, 6,6^{\prime}$-non-achlorobiphenyl (PCB-208) were purchased from AccuStandard (New Haven, CT, United States). Frozen whale blubber homogenate (SRM 1945) was obtained from the National Institute of Standards and Technology (Gaithersburg, MD, United States). A muscle filet of Pacific halibut (Hippoglossus stenolepis) purchased from a local market was used to demonstrate quantitative recovery of spiked target analytes. Optima grade dichloromethane (DCM), hexane, and acetone were purchased from Fisher Scientific (Fair Lawn, NJ, United States). Silica gel (60-200 mesh, J.T. Baker, Phillipsburg, NJ, United States) and alumina (60-325 mesh, Fisher Scientific) were activated overnight at 160 and $250^{\circ} \mathrm{C}$, respectively, deactivated with deionized water $(3 \%$ by weight) and stored in hexane. Sodium sulfate (Mallinckrodt, Phillipsburg, NJ, United States) and glassware were baked at $500^{\circ} \mathrm{C}$ for $4 \mathrm{~h}$ before use.

Subsamples of $0.1-0.5 \mathrm{~g}$ were cut from full depth blubber samples using a solvent rinsed stainless steel knife on a block of dry ice to prevent liquefaction. After weighing, each subsample was homogenized with kiln fired $\mathrm{Na}_{2} \mathrm{SO}_{4}$, spiked with an aliquot of surrogate solution (in hexane), and extracted with four cycles of DCM at $100^{\circ} \mathrm{C}$ and 1500 psi using a Dionex Accelerated Solvent Extraction (ASE) Model 300 system (Sunnyvale, CA, United States). The resulting extract was exchanged to hexane and concentrated for gravimetric lipid determination using a TurboVap 500 evaporator (Zymark, Hopkinton, MA, United States). After redissolution in 1:1 DCM/hexane (v:v), the sample extract was applied to a $50 \mathrm{~cm} \times 2.5 \mathrm{~cm}$ i.d. glass column packed with $40 \mathrm{~g}$ of SX-3 Bio Beads (Bio-Rad Laboratories,
Hercules, CA, United States) to remove lipid. Target analytes were eluted with 1:1 DCM/hexane (v:v) in the 75-220 $\mathrm{ml}$ fraction, and the collected extract was exchanged to hexane. This extract was further purified using alumina $(6 \mathrm{~cm})$ and silica gel $(12 \mathrm{~cm})$ in a $1.1 \times 30 \mathrm{~cm}$ glass column, eluting target analytes with $15 \mathrm{ml}$ hexane followed by $60 \mathrm{ml} 30 / 70 \mathrm{DCM} /$ hexane (v:v). The final extract was exchanged to hexane, reduced to $1.0 \mathrm{~mL}$, fortified with PCB 30 and PCB 205 (as internal quantitation standards), and stored at $-20^{\circ} \mathrm{C}$ prior to analysis.

Sample extracts were analyzed using an Agilent 7890 gas chromatograph (GC) coupled to a 5975C quadrupole massselective detector (MSD) operating in both electron ionization (EI) and negative chemical ionization (NCI) modes (Wilmington, DE, United States). Lower chlorinated PCB homologs (i.e., those with 4 chlorines or less) were analyzed in EI mode. The remaining PCB congeners, OCPs, and BDEs were analyzed in NCI mode using methane (99.97\% purity) as the reagent gas at $40 \%$ flow rate. Ultrahigh purity ( $>99.999 \%$ ) helium with a constant flow rate of $1 \mathrm{ml} / \mathrm{min}$ (EI mode) or $1.9 \mathrm{ml} / \mathrm{min}$ (NCI mode) was used as the carrier gas. One microliter of sample was injected through a split/splitless inlet operated isothermally at $300^{\circ} \mathrm{C}$ in splitless mode onto a DB-XLB column $(30 \mathrm{~m} \times 0.25 \mathrm{~mm} \times 0.25 \mu \mathrm{m}$, Agilent J\&W Scientific, Santa Clara, CA, United States). For $\mathrm{NCI}$ analysis, the oven temperature was programmed from $90^{\circ} \mathrm{C}$ ( $1 \mathrm{~min}$ hold) to $150^{\circ} \mathrm{C}$ at $5^{\circ} \mathrm{C} / \mathrm{min}$, to $260^{\circ} \mathrm{C}$ at $3^{\circ} \mathrm{C} / \mathrm{min}$, and to $320^{\circ} \mathrm{C}$ at $20^{\circ} \mathrm{C} / \mathrm{min}$ ( $5 \mathrm{~min}$ hold). The transfer line, ion source and quadrupole were maintained at 280,150 , and $150^{\circ} \mathrm{C}$, respectively. For EI mode, the oven temperature was programmed from $80^{\circ} \mathrm{C}$ ( $1 \mathrm{~min}$ hold) to $190^{\circ} \mathrm{C}$ at $5^{\circ} \mathrm{C} / \mathrm{min}$, to $260^{\circ} \mathrm{C}$ at $4^{\circ} \mathrm{C} / \mathrm{min}$, to $290^{\circ} \mathrm{C}$ at $20^{\circ} \mathrm{C} / \mathrm{min}$, and to $300^{\circ} \mathrm{C}$ at $50^{\circ} \mathrm{C} / \mathrm{min}(20 \mathrm{~min}$ hold $)$. The transfer line, ion source and quadrupole were maintained at 280,230 , and $150^{\circ} \mathrm{C}$, respectively. Mass spectral data were collected in selected ion monitoring (SIM) mode, and five-point internal standard calibration curves were used to quantify the target compounds.

Quality control and quality assurance for POPs included nominal analyte-specific reporting limits that ranged between 0.11 and $25 \mathrm{ng} / \mathrm{g}$ wet weight based on an extracted sample mass of $0.5 \mathrm{~g}$ and a $\mathrm{S} / \mathrm{N}$ of 5 . No target analytes were detected in procedural blanks. The mean ( \pm standard deviation) recoveries of DBOFB and BDE-172 were $58 \pm 6.0$ and $92 \pm 13 \%$ (Supplementary Table S3), respectively. The recovery of PCB208 was biased high and highly variable due to contribution of this congener already in the samples. For the subset of 10 samples with the lowest summed PCB concentrations (i.e., < $1000 \mathrm{ng} / \mathrm{g}$ ), the recovery of PCB-208 was $69 \pm 16 \%$. The recovery of 68 target analytes spiked into Pacific halibut muscle was $80 \pm 5.9$ and $93 \pm 7.6 \%$ for matrix spike and duplicate samples, with a mean relative percent difference (RPD) of $15 \pm 4.6 \%$. In addition, the mean RPD for estimated concentrations determined in a blubber sample analyzed in duplicate was $21 \pm 9.0 \%$. The mean recovery of 52 target analytes for which concentrations are certified in SRM1945 was $74 \pm 16 \%$. Target analyte concentrations reported on a wet weight basis were not corrected for surrogate recovery. The summary of performance-based Quality Assurance and Quality Control (QA/QC) is reported in Supplementary Table S2. 


\section{Mercury Analysis}

For total mercury (THg) analysis, nine skin samples $(\sim 0.1250 \mathrm{~g}$ wet weight) were added into the quartz sample boats (preheated to $650^{\circ} \mathrm{C}$ for three intervals of $3 \mathrm{~min}$ each to remove any impurity of mercury). Total $\mathrm{Hg}$ was determined via atomic absorption spectrophotometry, using a direct mercury analyzer DMA 80 (Milestones Srl, Italy), US EPA standard method 7473. The advantage of using this equipment is that the instrument does not require acid digestion of the sample or other pretreatment (Calle et al., 2018). Results were converted from wet weight (ww) to dry weight (dw) using a factor of 3.3 as determined in dolphin skin by Stavros et al. (2007). Therefore, all mercury concentrations are expressed as dry weight $(\mathrm{mg} / \mathrm{kg} \mathrm{dw})$.

Quality assurance methods included using procedural blanks by measuring empty boats (blanks), duplicates for two samples and certified reference material (DORM4: $0.412 \pm 0.036 \mathrm{mg}$ $\left.\mathrm{kg}^{-1}\right)$. Procedural lab blanks $(n=4)$ were run with the samples for $\mathrm{THg}$ analysis and no $\mathrm{Hg}$ contamination was found (<detection limit: $0.0001 \pm 0.00 \mu \mathrm{g} / \mathrm{kg}$ ). Analytical quality control was checked against the certified reference material (CRM DORM4 Fish Protein, certified reference material for trace metals provided by National Research Council Canada). Percentages of recovery of the reference material and blanks are shown in Supplementary Table S3.

\section{Data Treatment and Statistical Analysis}

Concentrations of POPs were blank-corrected using the method detection limit (i.e., MDL), defined here as the mean response of the levels measured in procedural blanks used plus threefold the standard deviation (SD) of the blanks (i.e., $\mathrm{MDL}=$ Mean $_{\text {blanks }}+3 \times \mathrm{SD}_{\text {blanks }}$ ) (see Alava et al., 2009, 2011). Concentrations of analytes below the MDL were adjusted using $1 / 2$ half of the MDL. However, as no concentrations for targeted analytes were detected in the procedural blanks, this precluded in using the MDL for non-detects; thus, as a substitution method for non-detects, the reporting limits (RL), which was estimated from the Instrument Detection Limit with $\mathrm{S} / \mathrm{N}=5$ (signal-to-noise ratio), divided to the square root of 2 (i.e., $R L / \sqrt{ } 2$ ) was used as the limit of detection (LOD) instead for each analyte or contaminant that was not detected $(<\mathrm{RL})$. Then, POP concentrations were lipid normalized by dividing the wet weight concentrations to the lipid fraction measured in the blubber samples to account for differences in the lipid content of the dolphin samples; and, thus expressed on a lipid weight basis (mg/kg lipid). For THg data, no blank correction was needed since no mercury concentration was detected in procedural blanks (below the limit of detection, <LOD).

The contaminant data for POP and THg was tested for normal distribution and the Kolmogorov-Smirnov and ShapiroWilk $W$ tests were used for normality. For homogeneity of variance, homoscedasticity (i.e., equal variance) was tested using the Brown-Forsythe test. As THg data were normally distributed $(p>0.05)$ with equal variances, a one-way ANOVA was used to compare concentration data between adult males and females and subadult females. When comparing the THg data between males and females, the statistical power of performed ANOVA test for THg data (with $\alpha=0.050$ ) was 0.098 and below the desired power of 0.800 due to small sample size. In general, contaminant data for POPs were normally distributed $(p>0.05)$ with homoscedasticity and met criteria for the homogeneity, except for the dieldrin data, which showed heteroscedasticity (i.e., unequal variances); thus, the non-parametric Kruskal-Wallis One Way Analysis of Variance on Ranks tests was run for sex comparisons of this particular POP substance. If a significant difference was found amongst the tested dolphin groups (adult males, adult females and subadult females), a Pairwise Multiple Comparison Procedure (Dunn's Method) to isolate the group or groups that differed from the other was also applied. Similar to the THg mercury data, the ANOVA statistical power $(\alpha=0.050)$ for the POP data was below the desired power of 0.800 .

\section{Health Risk Assessment}

A health risk assessment based on the toxic equivalent quotient (TEQ, ng/kg lipid) relative to 2,3,7,8-tetrachlorodibenzo- $p$ dioxin $(2,3,7,8$-TCDD) was calculated for PCBs detected in bottlenose dolphins by applying the most recent data for toxic equivalency factors (TEFs) established for dioxin-like PCBs (i.e., compounds that have chemical structures, physicalchemical properties, persistence, bioaccumulative capacity, lack of biotransformation and toxic responses similar to 2,3,7,8TCDD), including the planar (non-ortho) PCBs ( $\Sigma$ PCBs 77 , 81,126 , and 169) and mono-ortho PCBs ( $\Sigma$ PCBs 105, 114, $118,123,156,157,167$ and 189), as reported by Van den Berg et al. (2006). PCB 77, PCBs 81 and PCB 126 (75\% of non-ortho PCB congeners) were not included in the final TEQ calculations to prevent overestimation in the total sum of TEQs as these congeners were not originally detected in the set of dolphin samples. Likewise, РСВ 169 was not included, except for an adult female and subadult female, in which this non-ortho PCB congener was readily detected. The resulting data for TEQs were then compared to the TEQ threshold levels, including the no observable adverse effect level (NOAEL) and the lowest observable adverse effect level (LOAEL) for dioxin-like PCBs, derived from immunotoxic action and endocrine disruption endpoints assessed in aquatic mammals, i.e., harbor seals (Phoca vitulina) and killer whales (Orcinus orca) (Ross et al., 1995, 2000; Ross P. et al., 1996; Ross P. S. et al., 1996).

In an effort to further understand the health risk characterization, we attempted to interpret observed concentrations of POPs, including PCBs, PBDEs and DDTs (i.e., $p, p^{\prime}-D D E$ ), as well as mercury, in terms of potential related health effects by these pollutants such as immunotoxicity, endocrine disruption and neurotoxicity in marine mammals. In doing so, the relative frequency of the population sampled (i.e., dolphins) expressed as the normal probability density distribution function of the log of total PCBs ( $\Sigma$ PCB), log of total PBDEs ( $\Sigma$ PBDE), and log $p, p^{\prime}-\mathrm{DDE}$ concentrations measured in a lipid weight basis in dolphins (Gaussian distribution) was compared to the log values of lipid normalized toxic effect concentrations documented for PCBs (i.e., immunotoxicity and endocrine disruption, based on Ross P. S. et al., 1996; Kannan et al., 2000; Mos et al., 2010; Desforges et al., 2016); and the PCB-threshold affecting the population growth rate 
in bottlenose dolphins (Hall et al., 2005), for PBDEs (thyroid hormone endocrine disruption; Hall et al., 2003) and for DDTs [i.e., endocrine disruption by $p, p^{\prime}-\mathrm{DDE}$ as a potent antiandrogenic contaminant, following the approach formulated by Alava et al. (2011) based on Kelce et al. (1995)] to assess what proportion of the dolphins (i.e., frequency) exceed target threshold concentrations for a given contaminant. For mercury (THg), the log of THg (most of which was assumed to be $\mathrm{MeHg}$ for the eco-toxicological probabilistic risk assessment) was compared to mercury effect concentrations causing immunotoxicity, neurotoxicity and nephrotoxicity in marine mammals (Desforges et al., 2016).

\section{RESULTS AND DISCUSSION}

\section{Haplotypes and Sex Genotyping}

The mitochondrial DNA sequencing of skin samples from 11 different dolphins revealed that these individuals belonged to only two haplotypes. Nine (81.8\%; specimens EDM-1-18, EDM2-18, EDM-4/8-18, EDM-5-18, EDM-6-18, EDM-7-18, EDM-918, EDM-11/13-18, and EDM-12-18) were Haplotype 7, which is the most common haplotype for the inner estuary of the Guayaquil Gulf and the one that has also been documented at low frequencies in the outer estuary $(\sim 9 \%)$ (Bayas-Rea et al., 2018), while $18.2 \%$ (2/11; specimens EDM-3-18, EDM-10-18) were haplotype 9, a haplotype that has been found only in the inner estuary population and is the second most common haplotype there. These haplotypes are also very closely related, differing by only one nucleotide, a transition from a $\mathrm{T}$ in Hap 7 to a $\mathrm{C}$ in Hap 9, corresponding to a sequence divergence of $0.26 \%$ $(1 / 392)$. Haplotype diversity was only 0.327 , which is similar to the lowest estimate obtained by Bayas-Rea et al. (2018) for their inner estuary samples (El Morro site: $\mathrm{Hd}=0.286$ ). The analysis of the mitochondrial DNA sequences thus confirms that the specimens sampled were genetically consistent with the inner estuary population (i.e., coastal ecotype). Of the 11 specimens scored for sex, six (EDM-1-18, EDM-2-18, EDM-5-18, EDM-718, EDM-11/13-18, and EDM-12-18) were genetically identified as males and five (EDM-3-18, EDM-4/8-18, EDM-6-18, EDM-918, and EDM-10-18) were identified as females (Table 1).

The resident bottlenose dolphin population in the inner estuary of the Gulf of Guayaquil is genetically distinctive from bottlenose dolphin populations in other geographic regions and exhibits low genetic diversity (Bayas-Rea et al., 2018). Although sampling of bottlenose dolphins from the outer estuary of the Gulf of Guayaquil for genetic analysis has been sparse, genetic diversity appears much lower in the in the inner estuary population than in the outer estuary. In the largest population genetics study of dolphins in the area conducted to date, BayasRea et al. (2018) found nine different haplotypes for the 11 individuals sampled from the outer estuary $(\mathrm{Hd}=0.964)$, many of which clustered with haplotypes from the Gulf of California and the Galapagos Islands, indicating broad genetic admixture of the dolphins in this area. In contrast, they only found five haplotypes among the 37 individuals they sampled from the inner estuary (average $\mathrm{Hd}=0.557$ ). These formed a distinct genetic cluster relative to bottlenose dolphin populations from other geographic areas, with four of the five haplotypes only occurring in the inner estuary population. We only found two haplotypes, the two most common haplotypes in Bayas-Rea et al. (2018), among the nine specimens sampled in the current study. The genetic distinctiveness of the bottlenose dolphin population in the Gulf of Guayaquil inner estuary indicates the potential for local adaptation. Combined with the low genetic diversity, which suggests a small effective population size and genetic isolation, this population likely has a unique evolutionary heritage that could be lost if the population continues to decline.

\section{POP Concentrations}

No statistical differences in mean blubber concentrations between adult males and females and subadult female dolphins were found for POPs, except for dieldrin, which was significantly higher in subadult females when compared to adult females and males (Kruskal-Wallis One Way Analysis of Variance on Ranks, $\mathrm{H}=5.357, \mathrm{df}=2, p=0.029$; Figure 2). Total POP concentrations ( $\Sigma$ POP) measured in all dolphin samples was $44 \mathrm{mg} / \mathrm{kg} \mathrm{lw}$, ranging from $0.56 \mathrm{mg} / \mathrm{kg} \mathrm{lw}$ in an adult female to $13 \mathrm{mg} / \mathrm{kg} \mathrm{lw}$ in an adult male (Supplementary Table S4). The mean concentration \pm SD of $\Sigma$ PCB in adult females and males was $0.64 \pm 0.50 \mathrm{mg} / \mathrm{kg} \mathrm{lw}$ (range: $0.30-$ $1.0 \mathrm{mg} / \mathrm{kg} \mathrm{lw}$ ) and $3.65 \pm 1.50 \mathrm{mg} / \mathrm{kg} \mathrm{lw}$ (range: $2.65-$ $5.40 \mathrm{mg} / \mathrm{kg} \mathrm{lw}$ ), respectively (Figure 2 and Supplementary Table S4). $\Sigma$ PCB mean concentration in subadult females was $3.96 \pm 2.40 \mathrm{mg} / \mathrm{kg} \mathrm{lw}$ and comparable to that in adult males. Similar to PCBs, the mean concentration of organochlorines pesticides (OCPs) were relatively higher with adult males exhibiting $4.18 \pm 2.80 \mathrm{mg} / \mathrm{kg}$ lw (ranging 2.55 to $7.40 \mathrm{mg} / \mathrm{kg} \mathrm{lw}$ ) compared to adult females $0.66 \pm 0.605 \mathrm{mg} / \mathrm{kg} \mathrm{lw}$ (range: $0.24-$ $1.10 \mathrm{mg} / \mathrm{kg} \mathrm{lw}$ ). However, the subadult females contained OCP concentrations of $4.10 \pm 1.30 \mathrm{mg} / \mathrm{kg} \mathrm{lw}$, similar to adult males. DDTs were the dominant OCP measured in the dolphins' blubber samples, with a mean concentration of $0.57 \pm 0.550 \mathrm{mg} / \mathrm{kg}$ $\mathrm{lw}$ in adult females, and $4.0 \pm 2.72 \mathrm{mg} / \mathrm{kg} \mathrm{lw}$ in adult males (Figure 2 and Supplementary Table S4). Particularly, the mean concentration of $p, p^{\prime}$-DDE, the main DDT metabolite and a potent anti-androgenic chemical, was $0.46 \pm 0.50$ for adult females and $3.66 \pm 2.70$ in adult males, ranging from $0.12 \mathrm{mg} / \mathrm{kg} \mathrm{lw}$ in an adult female dolphin to $\sim 7.0 \mathrm{mg} / \mathrm{kg} \mathrm{lw}$ in an adult male. The $p, p^{\prime}$-DDE concentration in the subadult females was $3.30 \pm 1.15 \mathrm{mg} / \mathrm{kg}$ lw. PBDE concentrations were lower (i.e., adult males: $0.43 \pm 0.12 \mathrm{mg} / \mathrm{kg} \mathrm{lw}$; adult females: $0.17 \pm 0.095 \mathrm{mg} / \mathrm{kg} \mathrm{lw}$; and, subadult female: $0.48 \pm 0.15 \mathrm{mg} / \mathrm{kg}$ $\mathrm{lw})$. The concentrations for other OCPs, including dieldrin (range: 0.004 to $0.15 \mathrm{mg} / \mathrm{kg} \mathrm{lw}$ ) and chlordanes (range: 0.01 to $0.10 \mathrm{mg} / \mathrm{kg} \mathrm{lw}$ ), were the lowest detected in these dolphins, i.e., $<0.10 \mathrm{mg} / \mathrm{kg} \mathrm{lw}$ (Figure 2 and Supplementary Table S4).

\section{POP Composition Patterns}

As shown in Figure 2, the predominant POPs were OCPs accounting for $50 \%$ of $\Sigma$ POP, followed by PCBs (46\%) and PBDEs (6.0\%), although the concentration values of OCPs and PCBs were equally comparable. DDTs dominated the suit of 


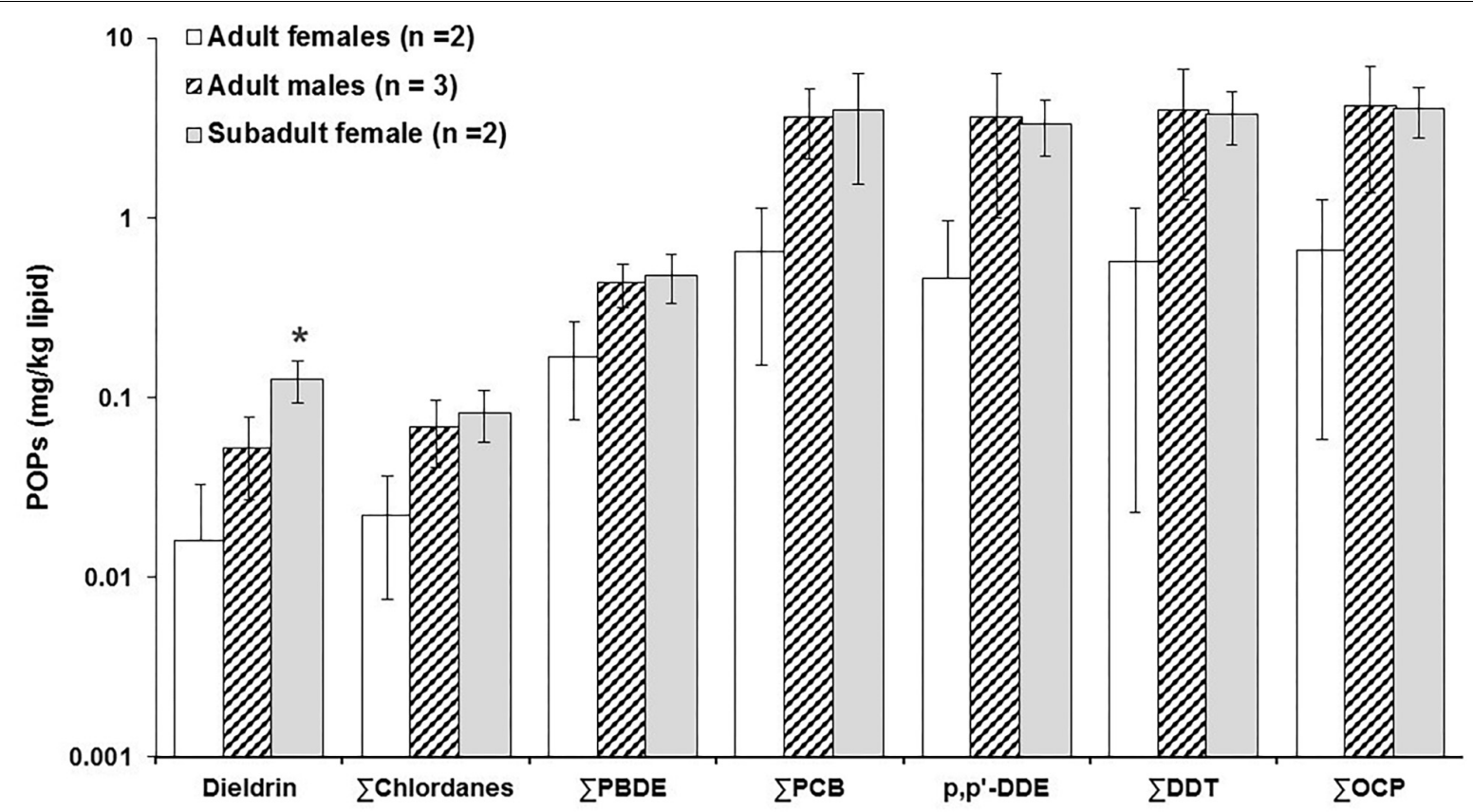

FIGURE 2 | Mean \pm SD of concentrations (mg/kg lipid weight) of dieldrin, $\Sigma$ Chlordanes, $\Sigma$ PBDE $\Sigma$ PCB, p, $\mathrm{p}^{\prime}$-DDE, $\Sigma$ DDT, and total organochlorine pesticides $(\Sigma O C P$ ) in blubber of adult (males and females) and subadult (females) bottlenose dolphins sampled in May 2018 in the El Morro Mangrove Wildlife Refuge (REVISEM), and Posorja Port, Gulf of Guayaquil, Ecuador. No significant differences were found between adult age categories of males and females and subadult females, except for Dieldrin, being significantly higher in subadult females, as indicated by the asterisk (*).

POPs, making up $47 \%$ of $\Sigma$ POP found in the El Morro bottlenose dolphins. For example, $p, p^{\prime}$-DDE contributed to $42 \%$ of $\Sigma$ POP, followed by PCB 153 (8\%) and PCB 180 (5\%). BDE 47, the dominant $\mathrm{PBDE}$ congener found in the dolphins, contributed $2 \%$ of $\Sigma$ POP. Other OCPs such as dieldrin and chlordanes ( $\Sigma$ Chlordanes) accounted for a total of $2 \%$ of $\Sigma$ POP (i.e., $1 \%$ each one). The congener composition profiles for PCBs and PBDEs are presented in Figures 3, 4, illustrating that PCB 153 , which is frequently the dominant recalcitrant congener, made up 16\% $\Sigma$ PCB (Figure 3) followed by PCB 180 (11\%), PCB 138 (8\%) and PCB 187 (7\%), while BDE 47, usually the dominant PBDE congener, accounted on average for up to $44 \%$ of $\Sigma$ PBDE, followed by BDE-100 (13\%), BDE-99 (10\%) and BDE-154 (8.0\%) (Figure 4).

$\mathrm{PCB}$ and $\mathrm{PBDE}$ patterns are in general agreement with the composition profiles for PCBs (Tanabe et al., 1988, 1997; Boon et al., 1997; Ross et al., 2000; Fair et al., 2010) and PBDEs (Rayne et al., 2004; Fair et al., 2007, 2010; Bachman et al., 2014) observed in cetaceans. In particular, hexa-chlorobiphenyls were the main PCB homolog class and dominated the composition profiles found in these dolphins. This finding is an indication that the dolphins from the Gulf of Guayaquil seem to be impacted by the common PCB contaminant signatures such as those resulting from residues of Aroclors 1242, 1254, and 1260 (Kucklick et al., 2011). In fact, hexa-chlorobiphenyls classically dominate PCB levels in cetaceans due to their wide use in the past and persistent nature in the marine environment (Boon et al., 1997; Tanabe et al., 1997; Aguilar et al., 2002; Fair et al., 2010). Conversely, there are documented special cases where uncommon Aroclors resulted in a clearly shifted homolog pattern dominated by a high proportion of octa- through deca-chlorobiphenyls in bottlenose dolphins exhibiting extremely high concentrations, i.e., Aroclor 1268 in coastal Georgia (GA, United States), including the Brunswick River Estuary and Sapelo Island (Pulster and Maruya, 2008; Kucklick et al., 2011). However, the PCB homolog pattern found in our dolphins are consistent with a non-Aroclor 1268 PCB formulations.

As for PBDEs, the predominant pattern of lower brominated congeners such as BDE-47, BDE-100, BDE-99, and BDE-154 (Figure 4) is also fairly consistent with the PBDE profile reported in bottlenose dolphins from the southeastern coast of the United States (Fair et al., 2007, 2010), small cetacean species (e.g., dolphins) from the Hawaiian Islands (Bachman et al., 2014) and blue whales from southern Chile (MuñozArnanz et al., 2019). The significance of BDE-47 at upper trophic levels in marine foodwebs reveals a combination of the tendency of this congener to biomagnify and its production through debromination pathways of other PBDE congeners in marine organisms (Boon et al., 2002; Rayne et al., 2004; Wolkers et al., 2004; Kelly et al., 2008).

\section{Mercury (THg)}

No statistical differences occurred in THg skin concentrations between male and female dolphins (one-way ANOVA, $p=0.310$; Figure 5). Concentrations of $\mathrm{THg}$ ranged from 1.92 in a subadult female dolphin to $3.63 \mathrm{mg} / \mathrm{kg} \mathrm{dw}$ in an adult male dolphin (Table 2). The mean concentration \pm SD of THg in adult females and males was $3.09 \pm 0.70 \mathrm{mg} / \mathrm{kg} \mathrm{dw}$ (range: $2.60-3.58 \mathrm{mg} / \mathrm{kg} \mathrm{dw}$ ) 


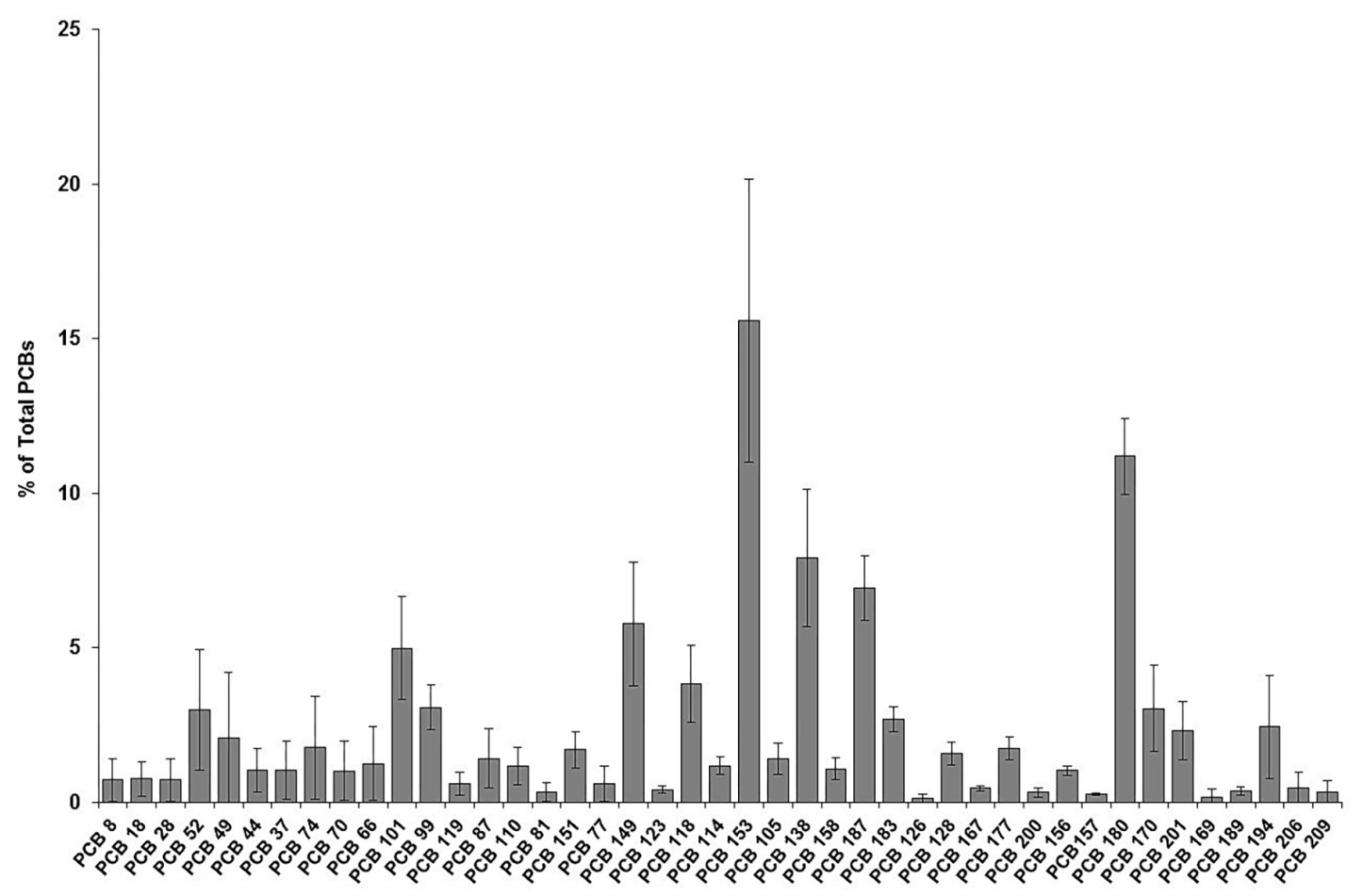

FIGURE 3 | Composition patterns of PCB congeners relative to total PCBs in blubber samples of bottlenose dolphins of the El Morro Mangrove Wildlife Refuge, and Posorja Port, Gulf of Guayaquil, Ecuador. The hexa-chlorobiphenyls, PCB 153, accounted for most of the proportion of PCBs.

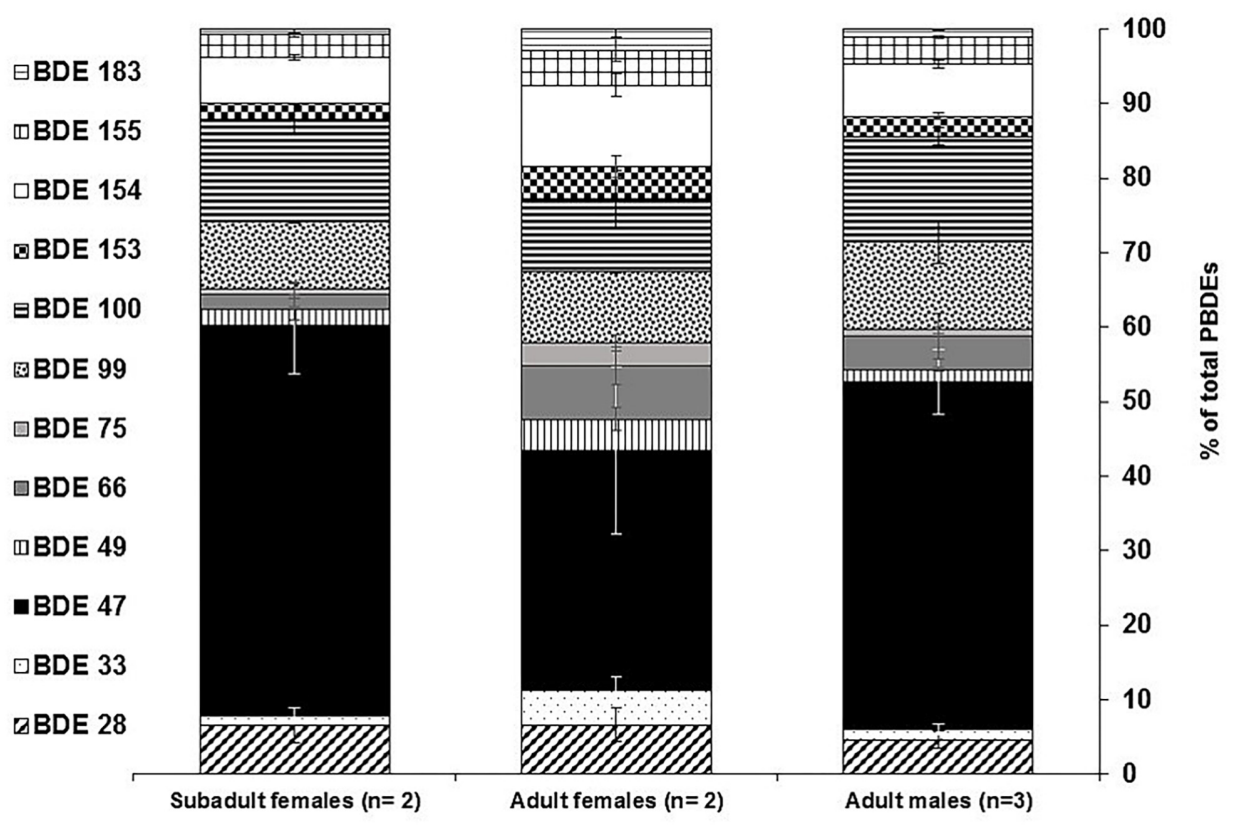

FIGURE 4 | Composition patterns of PBDE congeners relative to total PBDEs in blubber samples form bottlenose dolphins of the El Morro Mangrove Wildlife Refuge, and Posorja Port, Gulf of Guayaquil, Ecuador. BDE 47 contributed (black bars) to most of the PBDE composition.

and $3.16 \pm 0.64 \mathrm{mg} / \mathrm{kg} \mathrm{dw}$ (range: $2.43-3.63 \mathrm{mg} / \mathrm{kg} \mathrm{dw}$ ), respectively (Table 2 and Figure 5), while the $\mathrm{THg}$ mean concentration in the subadult females was $2.20 \pm 0.40 \mathrm{mg} / \mathrm{kg} \mathrm{dw}$.
Here, it is estimated that at least $70 \%$ of $\mathrm{THg}$ detected in our dolphin skin samples is organic mercury (i.e., methyl mercury, $\mathrm{MeHg}$ ) as about $72-73 \%$ of mercury found in skin of bottlenose 


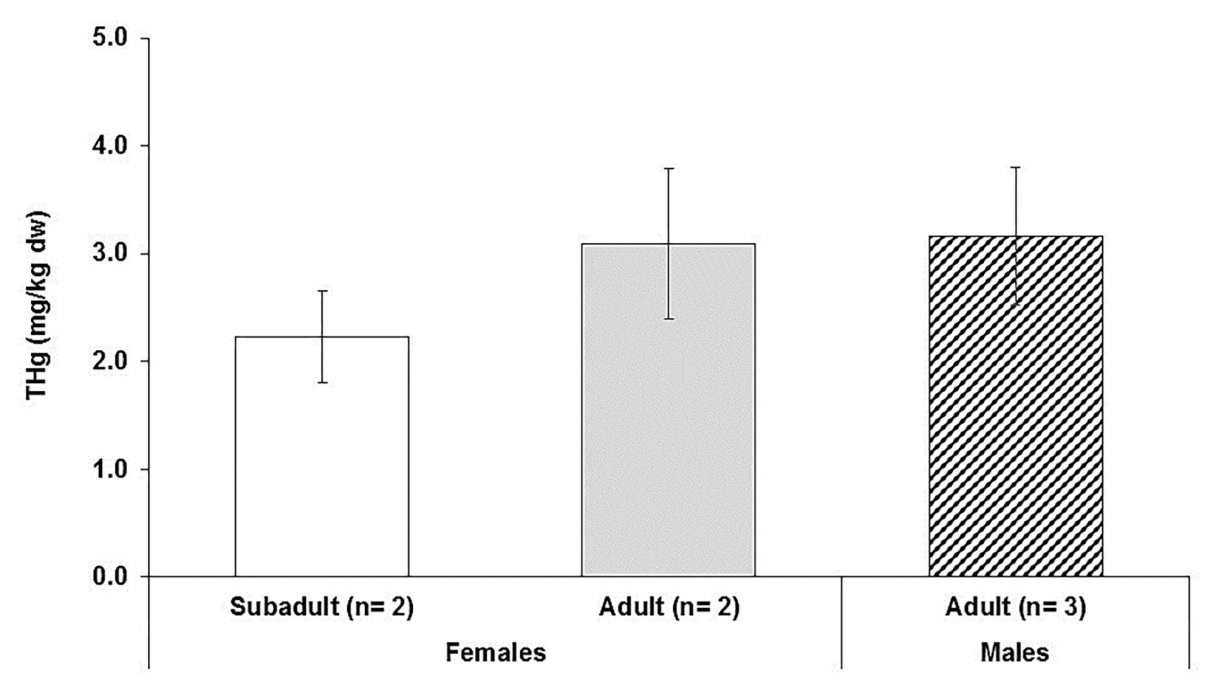

FIGURE 5 | Total mercury (THg) concentrations ( $\mathrm{mg} / \mathrm{kg}$ dry weight) detected in skin of free ranging bottlenose dolphins. The mean $\pm \mathrm{SD}$ of THg concentrations $(\mathrm{mg} / \mathrm{kg} \mathrm{dw})$ is shown for adult males and females and subadult females. No significant differences were found between adult age categories of males and females.

dolphins has been found to be MeHg (Stavros et al., 2007). We assumed that this $\mathrm{MeHg}$ percentage is a conservative value as most of the mercury existing in the skin of cetaceans and other marine mammal species is $\mathrm{MeHg}$, i.e., epidermal $\mathrm{MeHg}$ proportion ranging 90-100\% (Wagemann et al., 1998; Stavros et al., 2007; Woshner et al., 2008).

\section{Sex Differences: POPs and THg}

While no significant differences for the majority of the POP concentrations were found between adult individuals (males and females) and subadult females, likely due to the small sample size and thus lack of statistical power to perform a more robust comparison, the concentration of the organochlorine pesticide dieldrin was significantly higher in subadult females (Figure 2). Adult males showed fairly higher concentrations of dieldrin, $\Sigma$ Chlordanes, $\Sigma$ PBDE, $\Sigma$ PCB, and $\Sigma$ DDT relative to the concentration for each contaminant class measured in adult females (Figure 2). Contaminant loads of POP levels measured in blubber samples of sub-adult and adult males are

TABLE 2 | Total mercury (THg) concentrations in skin samples of bottlenose dolphins collected in May 2018 in the REVISEM, Gulf of Guayaquil, Ecuador.

\begin{tabular}{lcccc}
\hline Sample ID & Sex & $\begin{array}{c}\text { Field Evaluation } \\
\text { Size Class }\end{array}$ & $\begin{array}{c}\mathbf{T H g} \\
\mathbf{( m g} / \mathbf{k g} \mathbf{~ w w})\end{array}$ & $\begin{array}{c}\mathbf{T H g} \\
\mathbf{( m g} / \mathbf{k g ~ d w})\end{array}$ \\
\hline EDM-4/8-18* & Female & Subadult & 0.58 & 1.92 \\
EDM-6-18 & Female & Adult & 0.79 & 2.60 \\
EDM-9-18 & Female & Subadult & 0.765 & 2.53 \\
EDM-10-18 & Female & Adult & 1.085 & 3.58 \\
EDM-5-18 & Male & Adult & 0.74 & 2.43 \\
EDM-11/13-18* & Male & Adult & 1.04 & 3.42 \\
EDM-12-18 & Male & Adult & 1.10 & 3.63
\end{tabular}

*The THg concentration represent the mean of two samples (replicates) collected from the same individual. typically higher than those found in adult, reproductive females (Aguilar et al., 1999; Ross et al., 2000; Ylitalo et al., 2001; Wells et al., 2005; Dorneles et al., 2010). In this study, the subadult females also exhibited POP concentrations comparably higher to those observed in adult female dolphins (Figure 2). Contrasting to subadult females that have not yet reached the onset of sexual maturity and reproductive age, breeding adult females offload significant portions of their POPs burden through maternal transfer during gestation and lactation to calves, while males have no such mechanisms to offload contaminants (Borrell et al., 1995; Aguilar et al., 1999; Ross et al., 2000; Wells et al., 2005; Kajiwara et al., 2008).

Similar to POPs, the sex comparisons showed lack of significant differences in THg concentrations (Figure 5), which may also be due to small sample size. Adult females showed fairly higher skin $\mathrm{THg}$ concentration relative to the concentration in subadult females. In this study, the two subadult females exhibited $\mathrm{THg}$ skin concentration (i.e., $2.20 \pm 0.40 \mathrm{mg} / \mathrm{kg}$ $\mathrm{dw})$ comparably similar to those reported by Stavros et al. (2007). Skin concentrations of $\mathrm{THg}$ are typically higher in adult dolphin females than those found in adult male dolphins (Bryan et al., 2007; Stavros et al., 2007; Damseaux et al., 2017; Zanuttini et al., 2019).

\section{Geographical Comparisons: POPs and THg in Dolphins}

As no previous studies on POPs in bottlenose dolphins (T. truncatus) have been conducted in the El Morro Mangrove Wildlife Refuge or throughout the Gulf of Guayaquil, a geographical comparison of POP concentrations found in the blubber of The El Morro dolphins relative to levels observed in bottlenose dolphins and delphinid species from other geographical regions, including Gulf of Mexico, western North Atlantic Ocean and the Indo-Pacific Ocean, is presented 
TABLE 3 | Geographical comparisons between persistent organic pollutant data reported in the existing literature and the data of this study in the blubber of delphinid species from different locations (Pacific Ocean Gulf of Mexico, Indian Ocean and North Atlantic Ocean).

\begin{tabular}{|c|c|c|c|c|c|c|c|c|c|c|}
\hline Species & $n$ & $\begin{array}{l}\text { Age } \\
\text { category } \\
\text { and sex }\end{array}$ & $\begin{array}{c}\text { Sampling } \\
\text { location } \\
\text { (sampling period) }\end{array}$ & $\begin{array}{l}\text { POP data } \\
\text { reported }\end{array}$ & $\begin{array}{l}\text { Dieldrin } \\
\text { (mg/kg lw) }\end{array}$ & $\begin{array}{c}\Sigma \text { Chlordanes } \\
\text { (mg/kg lw) }\end{array}$ & $\begin{array}{c}\Sigma \text { PBDE } \\
\text { (mg/kg lw) }\end{array}$ & $\begin{array}{c}\Sigma P C B \\
\text { (mg/kg lw) }\end{array}$ & $\begin{array}{c}\Sigma D D T \\
\text { (mg/kg lw) }\end{array}$ & References \\
\hline \multirow[t]{2}{*}{$\begin{array}{l}\text { Tursiops } \\
\text { truncatus }\end{array}$} & 2 & $\mathrm{AF}$ & $\begin{array}{l}\text { El Morro Mangrove } \\
\text { Wildlife Refuge, } \\
\text { Gulf of Guayaquil, } \\
\text { Ecuador (2018) }\end{array}$ & Mean \pm SD & $0.02 \pm 0.02$ & $0.02 \pm 0.01$ & $0.17 \pm 0.09$ & $0.64 \pm 0.49$ & $0.57 \pm 0.55$ & This study \\
\hline & 3 & AM & & & $0.05 \pm 0.03$ & $0.07 \pm 0.03$ & $0.43 \pm 0.12$ & $3.65 \pm 1.52$ & $3.98 \pm 2.72$ & \\
\hline T. truncatus & 3 & Unknown & $\begin{array}{l}\text { Hawaiian Islands, } \\
\text { United States } \\
\text { (1997-2011) }\end{array}$ & Mean \pm SD & - & $1810 \pm 873$ & $1070 \pm 172$ & $11800 \pm 7340$ & $15000 \pm 7700$ & $\begin{array}{c}\text { Bachman et al. } \\
\text { (2014) }\end{array}$ \\
\hline $\begin{array}{l}\text { Seven delphinid } \\
\text { species }\end{array}$ & 8 & AM & & Median (range) & - & $\begin{array}{c}2335 \\
(1420-9520)\end{array}$ & $\begin{array}{c}395 \\
(94.8-1560)\end{array}$ & $\begin{array}{c}17050 \\
(7690-50200)\end{array}$ & $\begin{array}{c}23400 \\
(9730-99100)\end{array}$ & $\begin{array}{c}\text { Bachman et al. } \\
\text { (2014) }\end{array}$ \\
\hline \multirow[t]{2}{*}{$\begin{array}{l}\text { Sousa } \\
\text { chinensis }\end{array}$} & 12 & $\mathrm{AF}$ & $\begin{array}{l}\text { Pearl River Estuary, } \\
\text { China (2004-2013) }\end{array}$ & Mean \pm SD & $49.1 \pm 46.5$ & $61.2 \pm 60.2$ & - & $77700 \pm 59800$ & $1220 \pm 1850$ & Gui et al. (2014) \\
\hline & 7 & AM & & & $46.6 \pm 30.1$ & $48.2 \pm 29.7$ & - & $87200 \pm 66600$ & $1030 \pm 1450$ & \\
\hline $\begin{array}{l}\text { Stenella } \\
\text { longirostris }\end{array}$ & 21 & Unknown & $\begin{array}{l}\text { La Réunion } \\
\text { (south-western } \\
\text { Indian Ocean) } \\
\text { (2010-2011) }\end{array}$ & Median (range) & - & $20(0.5-65)$ & $60(10-120)$ & 955 (30-2170) & $432(49-1550)$ & $\begin{array}{l}\text { Dirtu et al. } \\
\text { (2016) }\end{array}$ \\
\hline $\begin{array}{l}\text { Tursiops } \\
\text { aduncus }\end{array}$ & 32 & Unknown & & & - & $10(0.3-45)$ & $95(5-1200)$ & $\begin{array}{c}5200 \\
(100-67500)\end{array}$ & 837 (26-19345) & \\
\hline \multirow[t]{2}{*}{ T. truncatus } & 30 & $\mathrm{AM}$ & $\begin{array}{l}\text { Sapelo Island, } \\
\text { Georgia } \\
\text { United States } \\
(2000-2007)\end{array}$ & $\begin{array}{c}\text { Geometric } \\
\text { mean }(95 \% \mathrm{Cl})\end{array}$ & $\begin{array}{c}0.16 \\
(0.13-0.21)\end{array}$ & $\begin{array}{c}6.16 \\
(4.50-8.40)\end{array}$ & $\begin{array}{c}3.98 \\
(3.10-5.12)\end{array}$ & 170 (126-229) & $\begin{array}{c}26.3 \\
(19.6-35.4)\end{array}$ & $\begin{array}{l}\text { Kucklick et al. } \\
\text { (2011) }\end{array}$ \\
\hline & 19 & AM & $\begin{array}{c}\text { Brunswick River } \\
\text { Estuary, Georgia, } \\
\text { United States } \\
(2000-2007)\end{array}$ & $\begin{array}{c}\text { Geometric } \\
\text { mean }(95 \% \mathrm{Cl})\end{array}$ & $\begin{array}{c}0.41 \\
(0.30-0.57)\end{array}$ & $\begin{array}{c}4.97 \\
(3.90-6.32)\end{array}$ & $\begin{array}{c}3.61 \\
(2.85-4.57)\end{array}$ & 450 (307-658) & $\begin{array}{c}26.1 \\
(19.0-36.0)\end{array}$ & $\begin{array}{l}\text { Kucklick et al. } \\
\text { (2011) }\end{array}$ \\
\hline \multirow[t]{2}{*}{ T. truncatus } & 6 & $\mathrm{AF}$ & $\begin{array}{l}\text { Biscayne Bay, } \\
\text { Florida, } \\
\text { United States } \\
\text { (2002-2004) }\end{array}$ & Median (range) & $\begin{array}{c}10.94 \\
(8.71-13.74)\end{array}$ & $39(31-51)$ & $21(14-31)$ & $891(574-1380)$ & $97(66-143)$ & Litz et al. (2007) \\
\hline & 31 & $\begin{array}{l}\text { AM, } \\
\text { juvenile }\end{array}$ & & & $\begin{array}{c}76.60 \\
(53.38-109.91)\end{array}$ & $\begin{array}{c}1070 \\
(777-1470)\end{array}$ & $394(300-520)$ & $\begin{array}{c}19900 \\
(13400-29400)\end{array}$ & $\begin{array}{c}2980 \\
(2370-3750)\end{array}$ & \\
\hline \multirow[t]{2}{*}{ T. truncatus } & 11 & $\mathrm{AF}$ & $\begin{array}{l}\text { Charleston, South } \\
\text { Carolina, } \\
\text { United States } \\
(2003-2005)\end{array}$ & Median (range) & $\begin{array}{c}160 \\
(20.6-1080)\end{array}$ & 777 (199-8570) & $\begin{array}{c}977 \\
(295-11300)\end{array}$ & $\begin{array}{c}14300 \\
(4540-131000)\end{array}$ & $\begin{array}{c}2900 \\
(1060-27300)\end{array}$ & $\begin{array}{l}\text { Fair et al. } \\
\text { (2010); Reif } \\
\text { et al. (2017) }\end{array}$ \\
\hline & 36 & AM & & & $\begin{array}{c}1420 \\
(414-2670)\end{array}$ & $\begin{array}{c}10900 \\
(3660-42800)\end{array}$ & $\begin{array}{c}5917 \\
(1711-13200)\end{array}$ & $\begin{array}{c}94000(28600- \\
255000)\end{array}$ & $\begin{array}{c}29000 \\
(14900-86,800)\end{array}$ & \\
\hline
\end{tabular}




\section{TABLE 3 | Continued}

\begin{tabular}{|c|c|c|c|c|c|c|c|c|c|c|}
\hline Species & $n$ & $\begin{array}{l}\text { Age } \\
\text { category } \\
\text { and sex }\end{array}$ & $\begin{array}{c}\text { Sampling } \\
\text { location } \\
\text { (sampling period) }\end{array}$ & $\begin{array}{l}\text { POP data } \\
\text { reported }\end{array}$ & $\begin{array}{l}\text { Dieldrin } \\
\text { (mg/kg lw) }\end{array}$ & $\begin{array}{c}\Sigma \text { Chlordanes } \\
\text { (mg/kg lw) }\end{array}$ & $\begin{array}{c}\Sigma \text { PBDE } \\
(\mathrm{mg} / \mathrm{kg} / \mathrm{lw})\end{array}$ & $\begin{array}{c}\Sigma P C B \\
(\mathrm{mg} / \mathrm{kg} \mathrm{Iw})\end{array}$ & $\begin{array}{c}\Sigma D D T \\
(\mathrm{mg} / \mathrm{kg} \text { Iw) }\end{array}$ & References \\
\hline \multirow[t]{2}{*}{ T. truncatus } & 15 & AF & $\begin{array}{l}\text { Indian River } \\
\text { Lagoon, Florida, } \\
\text { United States } \\
\text { (2003-2005) }\end{array}$ & Median (range) & $66.5(2.20-845)$ & $\begin{array}{c}1490 \\
(147-11200)\end{array}$ & $581(196-1420)$ & $\begin{array}{c}25500 \\
(1510-105000)\end{array}$ & $\begin{array}{c}4600 \\
(544-15200)\end{array}$ & \\
\hline & 33 & AM & & & $\begin{array}{c}356 \\
(1.70-1230)\end{array}$ & $\begin{array}{c}7600 \\
(2020-28800)\end{array}$ & $\begin{array}{c}1490 \\
(463-3790)\end{array}$ & $\begin{array}{l}79800 \text { (35000- } \\
227000)\end{array}$ & $\begin{array}{c}18600 \\
(6380-58400)\end{array}$ & \\
\hline \multirow[t]{2}{*}{ T. truncatus } & 29 & AF & $\begin{array}{l}\text { St. Andrew Bay, } \\
\text { Florida, } \\
\text { United States } \\
(2015-2016)\end{array}$ & Median (range) & $25(<1.2-170)$ & $200(<2-1400)$ & $\begin{array}{c}130 \\
(<2.1-710)\end{array}$ & $\begin{array}{c}3600 \\
(57-26000)\end{array}$ & $\begin{array}{c}3000 \\
(8.5-62000)\end{array}$ & $\begin{array}{l}\text { Galligan et al. } \\
\text { (2019) }\end{array}$ \\
\hline & 33 & AM & & & $34(8.7-130)$ & $590(170-2200)$ & 360 (62-800) & $\begin{array}{c}15000 \\
(1800-46000)\end{array}$ & $\begin{array}{c}14000 \\
(520-34000)\end{array}$ & \\
\hline \multirow[t]{2}{*}{ T. truncatus } & 11 & AF & $\begin{array}{l}\text { Normanno-Breton } \\
\text { Gulf (English } \\
\text { Channel), } \\
\text { United Kingdom } \\
\text { (2010-2012) }\end{array}$ & $\begin{array}{c}\text { Mean } \\
\text { (median) } \pm \mathrm{SD} \\
\text { (min-max } \\
\text { values) }\end{array}$ & $\begin{array}{c}180 \\
(137) \pm 147 \\
(59-344) n=3\end{array}$ & $\begin{array}{c}0.97 \\
(1.04) \pm 0.2 \\
(0.74-1.1) n=3\end{array}$ & $\begin{array}{c}639 \\
(214) \pm 686 \\
(51- \\
\left.2.14 \times 10^{3}\right)\end{array}$ & $\begin{array}{c}6.45 \times 10^{4} \\
\left(5.14 \times 10^{4}\right) \\
\pm 7.41 \times 10^{4} \\
\left(4.5 \times 10^{3}-\right. \\
\left.2.7 \times 10^{5}\right)\end{array}$ & $\begin{array}{c}104(7) \pm 144 \\
(6-434)\end{array}$ & $\begin{array}{l}\text { Zanuttini et al. } \\
\text { (2019) }\end{array}$ \\
\hline & 47 & AM & & & $\begin{array}{c}1.86 \times 10^{3} \\
\left(1.62 \times 10^{3}\right) \\
\pm 1.23 \times 10^{3} \\
(615- \\
\left.5.38 \times 10^{3}\right) \\
n=18\end{array}$ & $\begin{array}{c}25(15) \pm 28 \\
(3.9-99) n=18\end{array}$ & $\begin{array}{c}1.95 \times 10^{3} \\
\left(1.78 \times 10^{3}\right) \\
\pm 1.07 \times 10^{3} \\
(195- \\
\left.3.87 \times 10^{3}\right)\end{array}$ & $\begin{array}{l}1.33 \times 10^{5} \\
\left(1.14 \times 10^{5}\right) \\
\pm 7.89 \times 10^{4} \\
\left(1.75 \times 10^{4}-\right. \\
\left.3.93 \times 10^{5}\right)\end{array}$ & $\begin{array}{c}149(71) \pm 201 \\
(6-940)\end{array}$ & \\
\hline
\end{tabular}

POP concentrations are reported in mg/kg lipid weight (Iw) for adult males (AM) and females (AF). 
in Table 3. In general, the concentrations of El Morro bottlenose dolphins are lower when compared to concentration in bottlenose dolphins from more contaminated regions located in the Gulf of Mexico and along the United States east coast, as shown in Table 3 (Fair et al., 2010; Kucklick et al., 2011). For instance, adult male dolphins from our study exhibit $\Sigma$ PCBs and $\Sigma$ DDT concentrations well below the concentrations reported in male bottlenose dolphins sampled near Gulf of Mexico-Biscayne Bay (Litz et al., 2007), along the southeastern coast of US (Atlantic Ocean), including Charleston (South Carolina), and Indian River Lagoon, Florida (Reif et al., 2008; Fair et al., 2010), as well as St. Andrew Bay, Florida (Galligan et al., 2019). Likewise, the concentration in the El Morro dolphins are also much lower than those measured in highly contaminated bottlenose dolphins from the English Channel, i.e., Normanno-Breton Gulf (Zanuttini et al., 2019).

Interestingly, the concentrations of POPs detected in the dolphins assessed in this study exhibited similar concentrations to those measured in dolphin species (Stenella longirostris; T. aduncus) from La Reunion Island (Dirtu et al., 2016); however, the concentration in our dolphins were still lower when compared to the concentrations found in Indo-Pacific humpback dolphin (Sousa chinensis) from the Pearl River Estuary, China (Gui et al., 2014) and small cetacean species from Hawaii (Bachman et al., 2014) (Table 3).

The geographical comparison of $\mathrm{THg}$ concentrations measured in our dolphins to other studies is reported in Table 4. The concentrations of THg reported in this study were higher than those found in the skin of male and female bottlenose dolphins from waters of Charleston, South Carolina (i.e., averaging $\sim 1.7 \mathrm{mg} / \mathrm{kg} \mathrm{dw}$ ), but lower than the concentrations measured in male and female dolphins from the Indian River Lagoon, Florida (i.e., averaging $\sim 7.0 \mathrm{mg} / \mathrm{kg} \mathrm{dw}$ ) along the southeastern coast of United States (Stavros et al., 2007) and from Sarasota Bay in the west coast of Florida, Gulf of Mexico. Concentrations of $\mathrm{THg}$ in our male dolphins were similar to mercury concentrations measured in skin of male dolphin from the Lower Florida Keys (averaging $2.93 \mathrm{mg} / \mathrm{kg} \mathrm{dw}$ ); however, $\mathrm{THg}$ concentrations in our male and female dolphins were lower than the ones reported for the Florida Coastal Everglades (Damseaux et al., 2017) and for the Normano-Breton Gulf (English Channel) (Zanuttini et al., 2019). In comparison to the recent mercury concentrations reported for Commerson's dolphins (Cephalorhynchus commersonii) from Subantarctic marine waters (i.e., Southwestern South Atlantic Ocean) of Tierra del Fuego, Argentina (Cáceres-Saez et al., 2015), the THg concentrations in male bottlenose dolphins from REVISEM were higher than the concentrations reported in skin of male Commerson's dolphins, ranging 0.68-1.41 mg/kg dw, while for female dolphins the concentrations were similar, i.e., the THg concentration range in female Commerson's dolphins was 0.54-3.11 mg/kg dw (Cáceres-Saez et al., 2015).

The lower concentrations observed in the dolphins may be a plausible signal of the recent declines of POPs such as PCBs and DDTs in the global marine environment and some marine mammal populations although the exposure levels to POPs (e.g., PCBs) are still high in some cetacean species such as killer whale
(O. orca) and bottlenose dolphins in Europe (Jepson et al., 2016; Zanuttini et al., 2019), as well as in Arctic marine mammals, i.e., DDTs, PCBs, Chlordanes (Brown et al., 2018). The lack of POP baseline data at the regional level in the Gulf of Guayaquil precluded this study to make comparisons and to infer that the low concentrations found in the dolphins are affected by potential recent declines in emissions of these contaminants in the local environment. Conversely, it is reasonable to consider that a reduction in the application of DDT to control malaria in Ecuador during the last decades can be reflected in the low concentrations measured in the dolphins.

\section{Toxicological Health Effect Assessments}

The TEQ assessment is one of the approaches available to assess significantly toxic contribution of dioxin-like PCB congeners to wildlife and humans (Van den Berg et al., 2006; Fair et al., 2010). The total toxic equivalents ( $\Sigma$ TEQ) for non-ortho and mono-ortho (planar) PCBs in adult males (10 ng TEQ/kg lipid), and adult females (68 ng TEQ/kg lipid) are below the no observable adverse effects level (NOAEL-TEQ) thresholds of $90 \mathrm{ng} \mathrm{TEQ} / \mathrm{kg}$ lipid and the lowest observable adverse effects level (LOAEL-TEQ) of $209 \mathrm{ng}$ TEQ/kg lipid or $286 \mathrm{ng}$ TEQ/kg lipid for immunotoxic effects estimated in aquatic mammals, mainly in harbor seals (Ross et al., 1995; Ross P. S. et al., 1996; Kannan et al., 2000). The $\Sigma$ TEQ in these dolphins are also lower than toxic threshold level of $225 \mathrm{ng}$ TEQ/g lipid reported for killer whales from the northeastern Pacific (Ross et al., 2000). Exceptionally, the $\Sigma$ TEQ in the subadult females (363 ng TEQ/g lipid), significantly driven by the detection of the planar (non-ortho) PCB 169 (351 ng TEQ/g lipid) in one of the subadult females, exceeded these TEQ thresholds, highlighting the exposure to immunotoxic health effects by PCBs in this particular age class category.

Along with the TEQ risk assessment, the probabilistic cumulative (frequency) distribution shows that about 47 and 98\% of female and male dolphins exceeded the PCB-toxicity reference value (TRV) for immunotoxic and endocrine disruption (i.e., $1300 \mu \mathrm{g} / \mathrm{kg}$ lw or $1.3 \mathrm{mg} / \mathrm{kg} \mathrm{lw}$ ) estimated in harbor seals (PCB TRV reported by Mos et al. (2010), respectively (Figure 6A). In addition to exceeding this PCB TRV, 1 and $3 \%$ of females were above the PCB toxic effect concentration (PCB TEC) causing reproductive and immunotoxic impairments in marine mammals (17000 $\mu \mathrm{g} / \mathrm{kg}$ lw; Ross P. S. et al., 1996; Kannan et al., 2000), and the PCB threshold associated with a decrease in the population growth rate in bottlenose dolphins (i.e., $10000 \mu \mathrm{g} / \mathrm{kg}$ lw; Hall et al., 2005). PBDEs are also of concern due to their potential to disrupt the endocrine and immune systems (Meerts et al., 2001; Hallgren and Darnerud, 2002; Hall and Thomas, 2007; Frouin et al., 2010). Thus, the PBDE concentrations observed in dolphins were compared against the upper limit of PBDEs' threshold level $(1.5 \mathrm{mg} / \mathrm{kg} \mathrm{lw})$ associated with endocrine disruption of thyroid hormone in gray seals, Halichoerus grypus (Hall et al., 2003), showing that the PBDE concentrations in $0.3 \%$ of adult females were above the PBDE-endocrine disruption threshold, while $100 \%$ of adult males were below this threshold (Figure 6B).

Similarly, the risk characterization showed that the $\mathrm{p}, \mathrm{p}^{\prime}$ DDE concentrations in $4 \%$ of adult males and $8 \%$ of 
adult females exceeded the $\mathrm{p}, \mathrm{p}^{\prime}$-DDE anti-androgenic effect concentration reference value of $6890 \mu \mathrm{g} / \mathrm{kg} \mathrm{lw}(\sim 6.89 \mathrm{mg} / \mathrm{kg}$ $\mathrm{lw}$ ), i.e., applying the derivation from Alava et al. (2011) based on the p, $\mathrm{p}^{\prime}$-DDE anti-androgenic effect concentration of $64 \mu \mathrm{g} / \mathrm{kg}$ wet weight reported by Kelce et al. (1995), as shown in Figure 6C. This indicates that DDT concentrations in an important proportion of this small populations of dolphins are near levels expected to be associated with endocrine disruption.

As for mercury, Figure 6D shows that while 5 and $16 \%$ of female and male dolphins exceeded the effective concentration, causing 50\% reduction in lymphocyte function (THg EC50), of $810 \mu \mathrm{g} / \mathrm{kg}$ ww (0.81 mg/kg ww; Desforges et al., 2016), 100\% of female and male dolphins were above the THg threshold effect concentration (i.e., reducing lymphocyte proliferation) of $210 \mu \mathrm{g} / \mathrm{kg}$ ww $(0.21 \mathrm{mg} / \mathrm{kg}$ ww; Desforges et al., 2016), highlighting the risk of exposure to immunotoxic health effects by mercury in the population sampled.

The combined health effects of chemical mixtures, mainly the additive mode of immunotoxic action by these contaminants (i.e., immunotoxicity), can further compromise and modulate (i.e., downregulate or/and upregulate) both the immune and endocrine responses. Immune and endocrine systems that are compromised can affect the competence of the dolphins to fight disease and to effectively reproduce.

\section{Sources and Transport of POPs and Mercury in Dolphins' Habitat}

While local anthropogenic sources likely play an important role to contribute to chemical assaults, including POPs and mercury contamination, in the mangroves and wildlife reserves of the Gulf of Guayaquil (Calle and Alava, 2009; Fernández-Cadena et al., 2014; Calle et al., 2018), the long-range atmospheric transport of POPs and mercury to the Gulf of Guayaquil cannot be ruled out as a pathway to transferring pollutants to the habitat and marine predators in this tropical, equatorial region (Alava et al., 2009, 2011; Alava and Gobas, 2012; Alava and Ross, 2018). In fact, trans-Pacific air pollution of contaminants from tropical Asia to the eastern Pacific is a well-established mechanism (Iwata et al., 1993, 1994; Wilkening et al., 2000).

However, when examining the role of atmospheric transport as a pollution source of PCBs, which is a representative class of POPs subject to this mechanism (i.e., light PCB mixtures are more consistent with atmospheric signals), the contribution of the lower chlorinated PCB homolog groups such as di-, tri-,

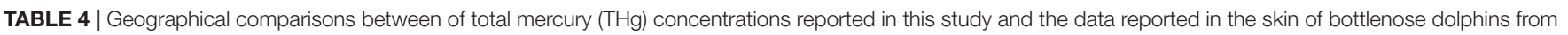
the southeast coast of United States and dolphins from the English Channel.

\begin{tabular}{|c|c|c|c|c|c|c|}
\hline Species & $\begin{array}{l}\text { Sample } \\
\text { size }(n)\end{array}$ & $\begin{array}{l}\text { Age category } \\
\text { and sex }\end{array}$ & Sampling location & $\begin{array}{l}\text { THg data } \\
\text { reported }\end{array}$ & THg (mg/kg dw) & References \\
\hline \multirow[t]{13}{*}{$\begin{array}{l}\text { Tursiops } \\
\text { truncatus }\end{array}$} & 2 & $\mathrm{AF}$ & $\begin{array}{l}\text { El Morro Mangrove Wildlife } \\
\text { Refugee, Gulf of Guayaquil, } 2018\end{array}$ & $\begin{array}{l}\text { Mean } \pm \text { SD } \\
(\min -\max )\end{array}$ & $\begin{array}{c}3.09 \pm 0.69 \\
2.60-3.58\end{array}$ & This study \\
\hline & 3 & AM & & & $\begin{array}{c}3.16 \pm 0.64 \\
2.43-3.63\end{array}$ & \\
\hline & 11 & $\mathrm{AF}$ & Sarasota Bay & $\begin{array}{l}\text { Mean } \pm \text { SD } \\
(\min -\max )\end{array}$ & $\begin{array}{c}12.73 \pm 4.80 \\
6.86-21.09\end{array}$ & Bryan et al. (2007) \\
\hline & 7 & AM & & & $\begin{array}{c}5.24 \pm 1.12 \\
3.83-6.63\end{array}$ & \\
\hline & 9 & AM & Lower Florida Keys & $\begin{array}{l}\text { Mean } \pm \text { SD } \\
(\min -\max )\end{array}$ & $\begin{array}{c}2.936 \pm 2.08 \\
0.294-5.71\end{array}$ & Damseaux et al. (2017) \\
\hline & 9 & $\mathrm{AF}$ & Florida Coastal Everglades & & $\begin{array}{c}12.31 \pm 8.73 \\
4.51-29.12\end{array}$ & \\
\hline & 13 & AM & & & $\begin{array}{c}10.05 \pm 6.64 \\
2.22-28.76\end{array}$ & \\
\hline & 11 & $\mathrm{AF}$ & Charleston South Carolina & $\begin{array}{l}\text { Mean } \pm \text { SD } \\
(\min -\max )\end{array}$ & $\begin{array}{c}2.1 \pm 0.65 \\
1.4-3.3\end{array}$ & Stavros et al. (2007) \\
\hline & 36 & AM & & & $\begin{array}{l}1.7 \pm 1.0 \\
0.77-4.9\end{array}$ & \\
\hline & 12 & AF & Indian River Lagoon, Florida & $\begin{array}{l}\text { Mean } \pm \text { SD } \\
(\min -\max )\end{array}$ & $\begin{array}{l}7.9 \pm 6.4 \\
0.37-17\end{array}$ & \\
\hline & 34 & AM & & & $\begin{array}{l}6.4 \pm 4.0 \\
0.33-15\end{array}$ & \\
\hline & 20 & $\mathrm{AF}$ & $\begin{array}{l}\text { Normanno-Breton Gulf (English } \\
\text { Channel) }\end{array}$ & $\begin{array}{c}\text { Mean } \\
\text { (median) } \pm \text { the } \\
\text { standard deviation } \\
\text { (min-max values) }\end{array}$ & $\begin{array}{c}11.2(9.24) \pm 5.69 \\
(3.03-21.3)\end{array}$ & Zanuttini et al. (2019) \\
\hline & 49 & AM & & & $\begin{array}{c}9.42(9.32) \pm 3.53 \\
\quad(2.45-17.4)\end{array}$ & \\
\hline
\end{tabular}

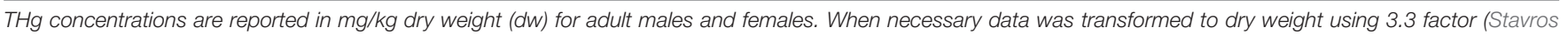
et al., 2007). $A F=$ adult female; $A M=$ adult male. 


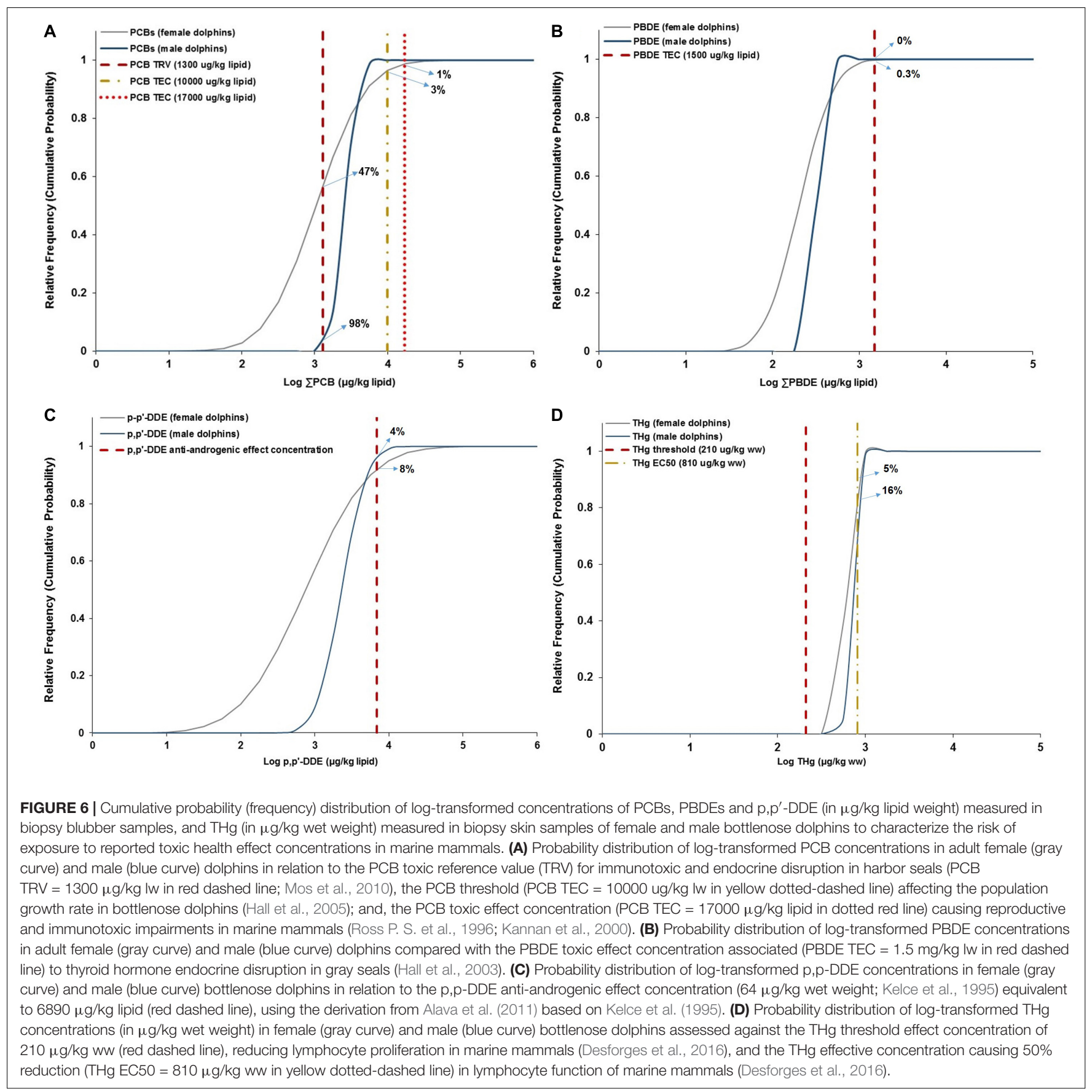

tetra- and penta-chlorobiphenyls (i.e., PCBs 8, 18, 28, 37, 44, 49, 52, 66, 70, 74, 77, 81, 87, 99, 101, 105, 110, 114, 118, 119, 123, and 126$)$ is relatively lower $(32.6 \%)$ compared to the proportion of highly chlorinated PCB homolog groups $(\sim 62 \%)$, including hexa- and hepta-chlorobiphenyls (i.e., PCBs 128, 138, 149, 151, $153,156,157,158,167,169,170,177,180,183,187,189$, and 194) as shown in Figure 7A. This finding suggests that most of the PCB contamination found in the exposed dolphins and habitat is likely to be originated from potential local sources, and less subjective to long-range atmospheric transport due to the low contribution of lighter PCB congeners predisposed to be transported and deposited from atmospheric pathways and sources. Contrasting to this PCB signature, a light PCB fingerprint by less chlorinated PCB congeners, indicating a common atmospheric source, was observed in Galapagos sea lions (Z. wollebaeki) from the remote Galapagos Archipelago (Alava et al., 2009; Alava and Gobas, 2012), located at $1000 \mathrm{~km}$ from the Gulf of Guayaquil.

Locally, oil or dielectric fluid contaminated with PCBs in transformers and containers of the grid electric system and facilities of urban and maritime areas (e.g., Guayaquil City, Posorja, Santa Elena) of the Gulf of Guayaquil are potential regional sources of these contaminants, requiring an urgent 
A

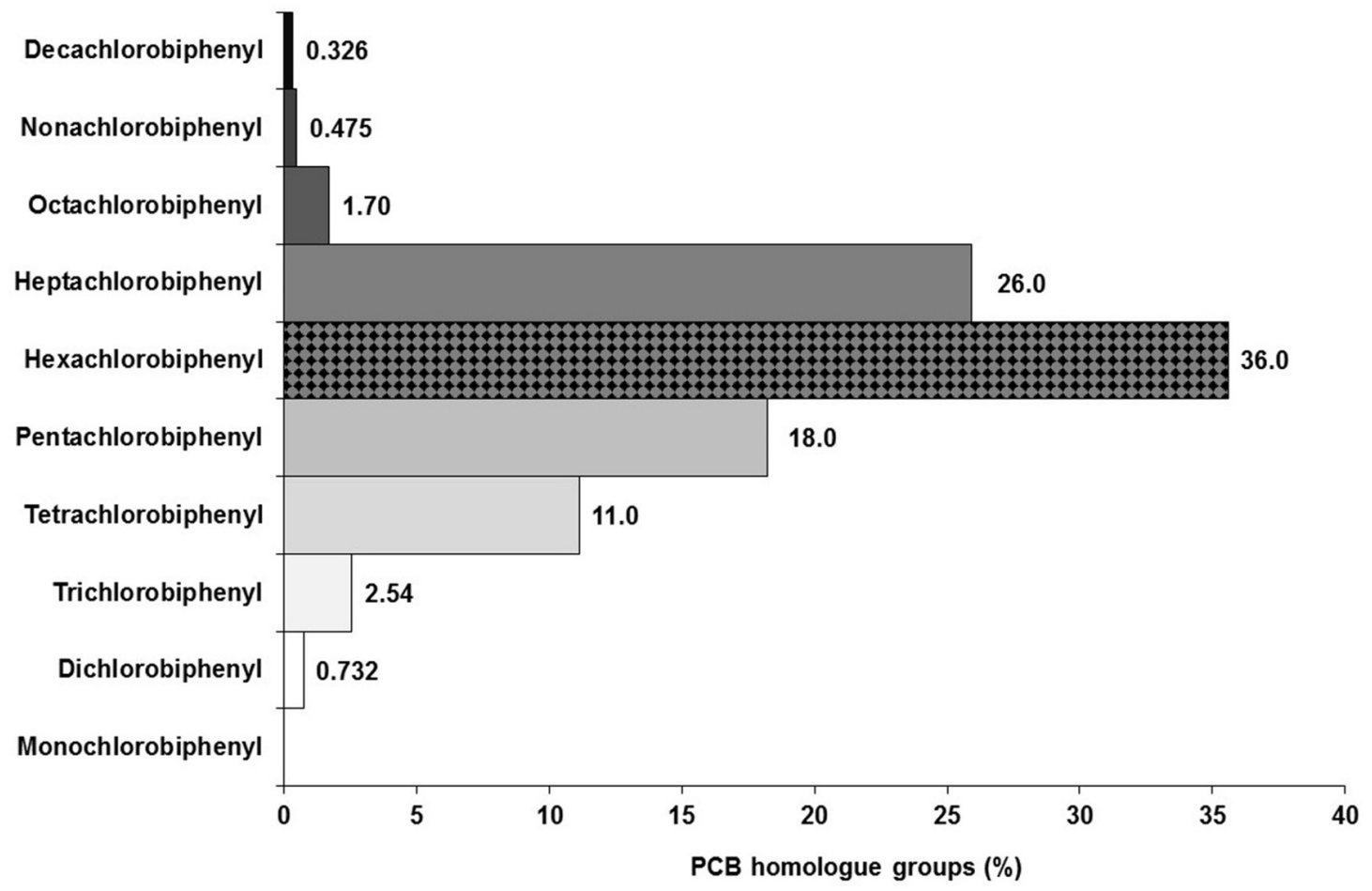

B

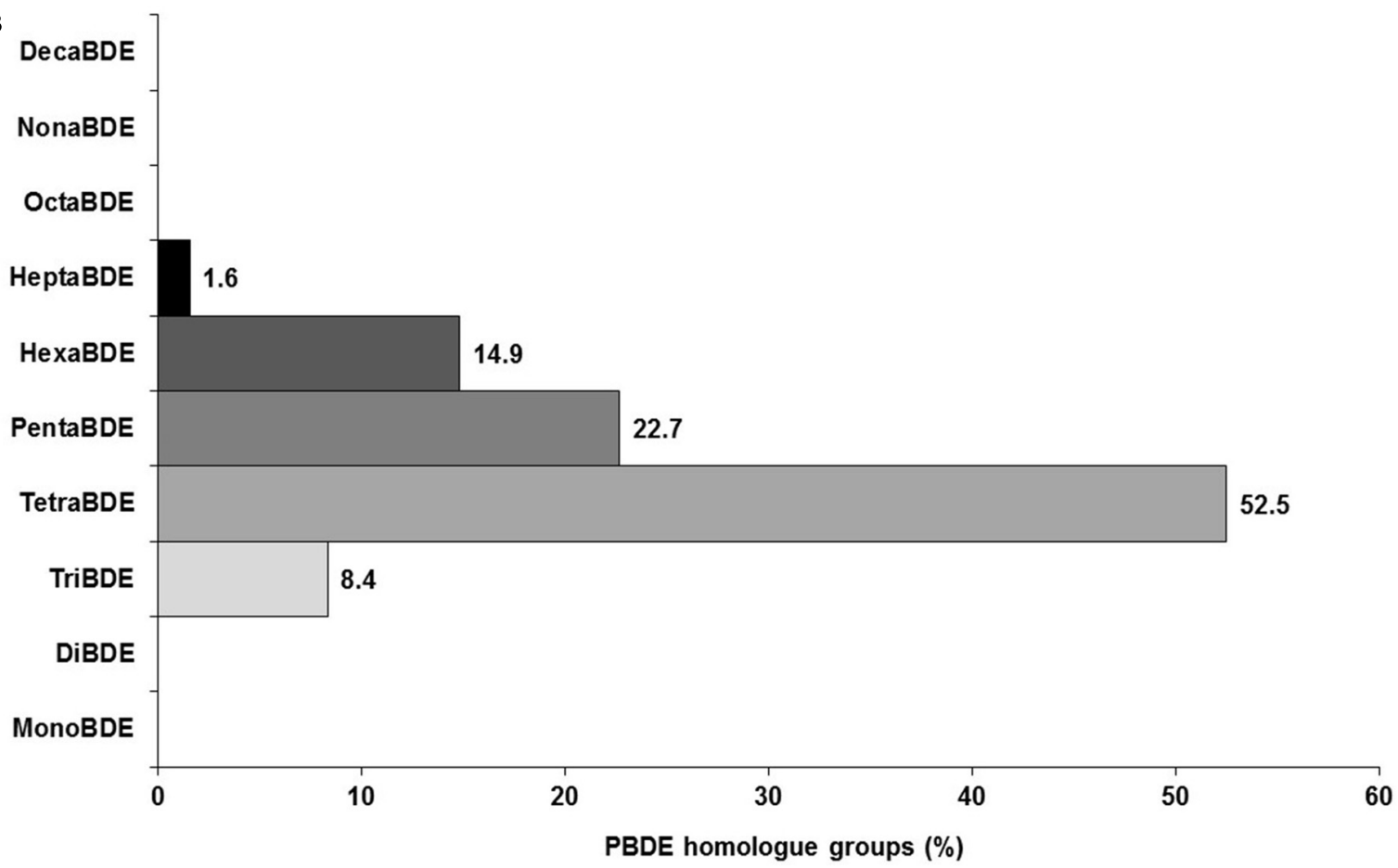

FIGURE 7 | Contribution of PCB (A) and PBDE (B) homolog groups showing the dominant patterns and distribution of lighter versus heavier homolog group signatures for both chemical classes observed in bottlenose dolphins sampled during May 2017 in El Morro Mangrove Wildlife Refuge, and Posorja Port, Gulf of Guayaquil, Ecuador.

hazardous waste management plan for treatment and elimination from these locations (MAE, 2006). To the best of our knowledge, Aroclor mixtures (e.g., Aroclor 1242, Aroclor 1254 and Aroclor
1260) have yet to be identified despite the absence of PCB production or industrial manufacturing in any chemical industry in Ecuador. Recently, certain assessments of these industrial 
POPs in transformers and capacitors from some electric power stations of the Guayaquil's Electric Corporation revealed that PCB levels found were in the order of $10 \mathrm{mg} / \mathrm{L}$ (CEMA, 2005). As it stands, the former national inventory of PCBs in Ecuador reported about 5,473,000 L of PCB-contaminated oilfluid used in abandoned, unused, and used electric transformers by the electric corporations (MAE, 2006). The dominance of PCB 153 in the PCB composition profile of these dolphins highlights the importance of this highly bioaccumulative and recalcitrant congener in non-Aroclor 1268 PCB formulations associated to urbanized areas and with human populations (Kucklick et al., 2011).

The prevalence of specific PBDE congeners detected in our dolphins (i.e., BDE-47, BDE-100, BDE-154, and BDE-99) is a finding coherent with studies suggesting common sources originating from use of penta-BDE ether flame retardant mixture (Hites, 2004; Kannan et al., 2005; Yogui and Sericano, 2009; Fair et al., 2010). Similarly, the disposal and incineration of solid waste products (i.e., computer, electronic devices and furniture), containing flame-retardant formulation mixtures, in landfills and open dumps can be potential sources of PBDE flame retardants (Alava et al., 2009). Comparable to PCBs, the longrange atmospheric transport cannot be ruled out as a potential pathway to deliver low brominated PBDEs to the dolphins' habitat as lighter PBDE homolog groups, including tetra- and penta-brominated diphenyl ethers (e.g., PBDEs 44, 47, 49, 66, 75, 99 and 100), dominated the overall pattern (75\%) found in the dolphins (Figure 7B). The PBDE congeners 47, 99 and 100 have been found to dominate air samples in the Northeastern Pacific (Noël et al., 2009). As air or rain samples have not been collected and analyzed for PBDEs in the Gulf of Guayaquil or coastal Ecuador, confirmation of the long-range atmospheric transport as a mechanism delivering PBDEs to this tropical region warrants further investigation.

In the recent past, the intra-domestic use of DDT inside homes and application in the agricultural sector between 1957 and 1999 in Ecuador to control the malaria mosquito vector (Anopheles sp.) and crop pests (MAE, 2004) echo the legacy of DDT contamination in the coastal and marine environment (Montaño and Resabala, 2005; Calle and Alava, 2009; Alava et al., 2011). In Ecuador, an application rate of about $134,000 \mathrm{~kg}$ of DDT per year was used by 1993, according to the national inventory of organochlorine pesticide use (MAE, 2004). While the use of DDT plummeted to around $1400 \mathrm{~kg} /$ year by 1998 and Ecuador halted DDT imports in 1994, a stock of $1636 \mathrm{~kg}$ of DDT was accessible for emergency response to combat malaria (MAE, 2004, 2006; Alava et al., 2011).

With the aim to further understand the pollution fingerprint by POPs, mainly the dominant OCPs (i.e., DDTs), the $p, p^{\prime}$ DDE/DDT ratio was calculated to assess the chronology of DDT historical inputs (Aguilar, 1984; Addison et al., 1986; Tanabe et al., 1997; Alonso et al., 2010; Kucklick et al., 2011) and infer the exposure time, based on the notion that native DDT is being biotransformed to its primary metabolite DDE over time (Addison et al., 1986; Alava et al., 2011). As it stands, a $p, p^{\prime}$ $\mathrm{DDE} / \mathrm{DDT}$ ratio $>0.6$ is an indication of a stable system with a long period of reaction (i.e., more DDE relative to the amount of DDT) with no new DDT inputs (Aguilar, 1984; Tanabe et al., 1997; Alonso et al., 2010; Alava et al., 2011). Thus, the high ratio $p, p^{\prime}$-DDE/DDT found here (i.e., 0.81-0.92) indicates a plausible scenario of past DDT contamination and minor contributions from new or current DDT sources. This ratio is consistent with and similar to the ratio (0.91-0.94) observed in Galapagos sea lions from the remote Galapagos Islands (Alava et al., 2011) and the ratio (i.e., 0.80) found in Guiana dolphin (Sotalia guianensis) from São Paulo, Brazil (Alonso et al., 2010).

The presence of dieldrin and chlordanes in these dolphins is fairly consistent with detection of these legacy OCPs in Galapagos sea lions and highlights the past use in the region coupled with the atmospheric transport and deposition of more volatile halogenated contaminants, i.e., organochlorine pesticides (Alava and Gobas, 2012; Alava and Ross, 2018).

The mercury exposure in our dolphins indicates mercury contamination in their habitat. While mercury isotopes' analyses were not conducted in this study to discriminate natural from human-made sources, possible anthropogenic sources of mercury in the Gulf of Guayaquil can include small scale and artisanal gold mining in southern Ecuador (Tarras-Wahlberg et al., 2000; Betancourt et al., 2012; Carling et al., 2013), and emissions from urbanization and industrialization in the Gulf of Guayaquil (Calle et al., 2018). Evidence of chronological emissions of anthropogenic mercury (i.e., amalgamation and cinnabar mining) during Inca, colonial and pre-industrial times (i.e., augmented preindustrial pollution by mercury from 1400 to $1600 \mathrm{AD}$ ) in the Andean region of South American can also corroborate the regional atmospheric transport of mercury emissions to this region since preindustrial times (Cooke et al., 2013; Alava and Ross, 2018). In fact, the mangroves of the Guayaquil Gulf are considered as one of the most contaminated tropical ecosystems by heavy metal pollution in the world (Fernández-Cadena et al., 2014; Calle et al., 2018).

\section{Dolphin Conservation and Pollutant Management Implications}

Anthropogenic stressors such as habitat perturbation, fisheries interactions, and biological and chemical pollution threatens the survival of the inner estuary population of bottlenose dolphins in REVISEM in the long term (Jiménez et al., 2011; Jiménez and Alava, 2014; Alava et al., 2019). Jiménez and Alava (2014) provided recommendations to undertake new lines of research, including assessment of pollutants, and improve the conservation of coastal bottlenose dolphins in Ecuador. As found in this study, bottlenose dolphins from the REVISEM are contaminated by POPs and mercury, demonstrating that these contaminants have reached high trophic level organisms in the Gulf of Guayaquil. Being the first assessment of POPs and mercury in a resident cetacean species in Ecuador's mainland coast, our findings and conclusions must be interpreted with caution given the limited sample size of dolphin blubber biopsies collected for contaminant analysis. However, following the precautionary approach, management actions are required to address and mitigate pollution in the region to enhance the conservation efforts for the recovery of the dolphin's population. 
Both international and national instruments and policies should be taken into consideration for an effective management and control of POPs and mercury within the context of hazardous substances for marine fauna and public health. As a signatory nation of the Stockholm Convention on POPs since May 2001, which was ratified on 7 June 2004, Ecuador fostered the National Plan for the Implementation of POP Management and executed the POP national inventory, including $\mathrm{PCBs}$, dioxins/furans, and OC pesticides (MAE, 2006). Thus, continuation of the mandate of the Stockholm Convention on POPs requires additional efforts and local regulation to protect the most productive estuary in the Pacific coast of South America and its species, including cetaceans.

Along these lines, Ecuador also signed (2013) and ratified (2016) the Minamata Convention on Mercury to control, reduce, and eliminate mercury emissions, and regulate gold mines (UNEP, 2016). Notwithstanding, gold mining, both artisanal and small-scale mining, is still a grave source of mercury pollution in Ecuador's continental coast, particularly in the Gulf of Guayaquil.

Recent dredging operations and disposal at sea have emerged as a looming threat for the population health and survival of these dolphins in the studied area (Jiménez and Alava, 2014; Alava et al., 2019). While environmental impact assessments of the El Morro Channel and Posorja deepwater port have evaluated the health effects on marine biota, mainly macroinvertebrates and other marine fauna, including local dolphins (Inocar, 2008; Ramón-Jibaja, 2018), a more rigorous approach was lacking to assess the negative impacts on the dolphin resident population of REVISEM and waters off Posorja (Alava et al., 2019). In the face of coastal project developments and dredging activities in the Gulf of Guayaquil, a proactive approach following the precautionary principle to prevent pollution is also recommended.

The adoption of a prevention pathway for policy an decision makers should be part of a framework to internalize and enforce a more transparent and comprehensive decision-making processes taking into account the conservation of marine wildlife and the trade-offs between anthropogenic development and protection of the marine environment and public health. In addition to the precautionary approach, an adaptive monitoring strategy to promote a management action plan to control and minimize pollution impacts by emerging contaminants of concern (Maruya et al., 2014; Alava, 2019) can be an important tool to be fostered in protected areas and sensitive marine ecosystems such as El Morro Refuge, to conserve this unique genetically identified inner estuary population of bottlenose dolphins.

\section{DATA AVAILABILITY STATEMENT}

The datasets generated for this study can be found in the GenBank accession numbers for the nucleotide sequences are as follows: BankIt2 308448 EDM-13-18 MT005756; BankIt2 308485 EDM-1-18 MT005757; BankIt2 308485 EDM-2-18 MT005758; BankIt2 308485 EDM-3-18 MT005759; BankIt2 308485 EDM-4-18 MT005760; BankIt2 308485 EDM-5-18 MT005761; BankIt2 308485 EDM-6-18 MT005762; BankIt2 308485 EDM-7-18 MT005763; BankIt2 308485 EDM-8-18
MT005764; BankIt2 308485 EDM-9-18 MT005765; BankIt2 308485 EDM-10-18 MT005766; BankIt2 308485 EDM-11-18 MT005767; BankIt2 308485 EDM-12-18 MT005768; BankIt2 308485 EDM-13-18 MT005769.

\section{ETHICS STATEMENT}

The animal study was reviewed and approved by the National Department of Marine Fisheries [NOAA Fisheries, US National Marine Fisheries Services, Authorizations and Permits for Protected Species (APPS), NMFS Permit No. 22062]; The Society for Marine Mammalogy (SMM) Ethics Committee reviewed the field methods and sample collection protocols for dart-biopsy sampling in bottlenose dolphins of the El Morro Mangrove Wildlife Refuge (Gulf of Guayaquil, Ecuador) and found no violations of the stated and written Society Guideline 4.6 ("4.6. Blood and tissue sampling”) available on the Society website.

\section{AUTHOR CONTRIBUTIONS}

JA: conceptualization of original idea, study design, supervision, field work, overall writing-original draft, statistical, and data analysis, review, and editing, supervision. PC and AT: field work, mercury analysis, writing, statistical, and data analysis. GB: field sampling (dart-biopsy sample collection with the crossbow). OA: skin sample preparation and mercury analysis. KM and WL: analysis of blubber samples for persistent organic pollutants (POPs) and writing for POP analytical methodology section. WA: genetics analysis: sex genotyping and haplotypes sequencing; writing of genetics sections and editing. PJ: field work, guidance, project administration, identification of dolphins for sampling and photo-identification. GD: field work, mercury analysis, writing, formatting, and editing. GDB: supervision, resources, and funding acquisition. PF: conceptualization, study design, field work, supervision, funding acquisition, project administration, writing-review, and editing.

\section{FUNDING}

Funding for travel and field work was provided by the Georgia Aquarium (GA, United States), the Samuel Freeman Charitable Trust, and South Carolina Aquarium (Charleston, SC, United States). The U.S. Fulbright Award was granted to $\mathrm{PF}$ to conduct conservation efforts and research of cetaceans in Ecuador. JA received research funding from the Nippon Foundation.

\section{ACKNOWLEDGMENTS}

This work is dedicated in the memory of the late Dr. Greg Bossart (1951-2019), who was a very close friend and colleague and one of the pioneers of dolphin health assessment projects along the southeast coast of United States. Permit for sampling and import of bottlenose dolphins was granted by the National 
Department of Marine Fisheries [NOAA Fisheries, US National Marine Fisheries Services, Authorizations and Permits for Protected Species (APPS), NMFS Permit No. 22062] of the United States and Ministerio de Ambiente del Ecuador/Ministry of Environment of Ecuador (MAE) with permit 029-2017-IC-FLO/FAU-DPAG/MAE. The Society for Marine Mammalogy (SMM) Ethics Committee reviewed the field methods and sample collection protocols for dartbiopsy sampling in bottlenose dolphins of the El Morro Mangrove Wildlife Refuge (Gulf of Guayaquil, Ecuador) and in compliance with the Society Guideline 4.6 ("4.6. Blood and tissue sampling") available on the Society website. We thank the U.S. Fulbright Award for PF to conduct conservation

\section{REFERENCES}

Addison, R. F. (1989). Organochlorines and marine mammal reproduction. Can. J. Fisher. Aquat. Sci. 46, 360-368. doi: 10.1139/f89-047

Addison, R. F., Zinck, M. E., and Smith, T. G. (1986). PCBs have declined more than the DDT group residues in Arctic ringed seals (Phoca hispida) between 1972 and 1981. Environ. Sci. Technol. 20, 253-256. doi: 10.1021/es00145a005

Aguilar, A. (1984). Relationship of DDE/ $\Sigma$ DDT in marine mammals to the chronology of DDT input into the ecosystem. Can. J. Fisher. Aquat. Sci. 41, 840-844. doi: 10.1139/f84- 100

Aguilar, A., Borrell, A., and Pastor, T. (1999). Biological factors affecting variability of persistent pollutant levels in cetaceans. J. Cetacean Res. Manag. 1, 83-116.

Aguilar, A., Borrell, A., and Reijnders, P. (2002). Geographical and temporal variation in levels of organochlorine contaminants in marine mammals. Mar. Environ. Res. 53, 425-452. doi: 10.1016/s0141-1136(01)00128-3

Aguirre, W. E., Shervette, V. R., Navarrete, R., Calle, P., and Agorastos, S. (2013). Morphological and genetic divergence of Hoplias microlepis (Characiformes: Erythrinidae) in rivers and artificial impoundments of Western Ecuador. Copeia 31:312. doi: $10.1643 / \mathrm{ci}-12-083$

Alava, J. J. (2019). "Legacy and emerging pollutants in marine mammals' habitat from british columbia: management perspectives for sensitive marine ecosystems," in Stewarding the Sound; the Challenge of Managing Sensitive Ecosystems, eds L. Bendell, P. Gallaugher, S. McKeachie, and L. Wood, (Boca Raton, FL: CRC Press), 87-114. doi: 10.1201/9780429025303-9

Alava, J. J., Cheung, W. W. L., Ross, P. S., and Sumaila, R. U. (2017a). Climate change-contaminant interactions in marine food webs: towards a conceptual framework. Glob. Change Biol. 2, 3984-4001. doi: 10.1111/gcb.13667

Alava, J. J., Denkinger, J., Jiménez, P. J., Carvajal, R., and Salazar, S. (2017b). "Population status, anthropogenic stressors and conservation of the Galapagos fur seal (Arctocephalus galapagoensis): an overview," in Tropical Pinnipeds, BioEcology, Threats and Conservation, ed. J. J. Alava (Boca Raton, FL: CRC Press), 134-145.

Alava, J. J., Ikonomou, M. G., Ross, P. S., Costa, D., Salazar, S., Aurioles-Gamboa, D., et al. (2009). Polychlorinated biphenyls and polybrominated diphenyl ethers in Galapagos sea lions (Zalophus wollebaeki). Environ. Toxicol. Chem. 28, 2271-2282. doi: 10.1897/08-331.1

Alava, J. J., Jiménez, P. J., Tirape, A., Calle, P., Alavarado-Cadena, O., Dominguez, G., et al. (2019). El Canario en la mina de carbón: delfines bufeos (Tursiops truncatus) del Golfo de Guayaquil como centinelas de polución marino-costera en Ecuador. Acta Oceanográfica del Pacifico 23, 57-65.

Alava, J. J., Ross, P. S., Ikonomou, M. G., Cruz, M., Jimenez-Uzcátegui, G., Dubetz, C., et al. (2011). DDT in endangered Galapagos sea lions (Zalophus wollebaeki). Mar. Pollut. Bull. 62, 660-671. doi: 10.1016/j.marpolbul.2011.01.032

Alava, J. J., and Gobas, F. (2012). “Assessing biomagnification and trophic transport of persistent organic pollutants in the food chain of the Galápagos sea lion (Zalophus wollebaeki): conservation and management implications," in New Approaches to the Study of Marine Mammals, eds A. Romero, and E. O. Keith (Rijeka: InTech), 77-108.

Alava, J. J., and Ross, P. S. (2018). "Pollutants in tropical marine mammals of the galápagos islands, ecuador: an ecotoxicological quest to the last eden," in Marine efforts and research of cetaceans in Ecuador. We thank Juan Moreno (MAE/REVISEM), Jorge Ortega (MAE), Leonardo Alava (MAE) and Diana Cárdenas (ESPOL and Pacific Whale Foundation) for field assistance, and the REVISEM park rangers for escorting the boat and providing surveillance for the dolphins sampling.

\section{SUPPLEMENTARY MATERIAL}

The Supplementary Material for this article can be found online at: https://www.frontiersin.org/articles/10.3389/fmars. 2020.00122/full\#supplementary-material

Mammal Ecotoxicology, eds M. C. Fossi, and C. Panti (Amsterdam: Elsevier), 213-234. doi: 10.1016/b978-0-12-812144-3.00008-5

Alonso, M. B., Eljarrat, E., Gorga, M., Secchi, E. R., Bassoi, M., Barbosa, L., et al. (2012). Natural and anthropogenically-produced brominated compounds in endemic dolphins from Western South Atlantic: another risk to a vulnerable species. Environ. Pollut. 170, 152-160. doi: 10.1016/j.envpol.2012.06.001

Alonso, M. B., Feo, M. L., Corcellas, C., Gago-Ferrero, P., Bertozzi, C. P., Marigo, J., et al. (2015). Toxic heritage: maternal transfer of pyrethroid insecticides and sunscreen agents in dolphins from Brazil. Environ. Pollut. 207, 391-402. doi: 10.1016/j.envpol.2015.09.039

Alonso, M. B., Marigo, J., Bertozzi, C. P., Santos, M., Taniguchi, S., and Montone, R. (2010). Occurrence of chlorinated pesticides and polychlorinated biphenyls (PCBs) in Guiana dolphins (Sotalia guianensis) from ubatuba and baixada santista. São Paulo, Brazil. Latin Am. J. Aquat. Mamm. 8, 123-130.

Bachman, M. J., Keller, J. M., West, K. L., and Jensen, B. A. (2014). Persistent organic pollutant concentrations in blubber of 16 species of cetaceans stranded in the Pacific Islands from 1997 through 2011. Sci. Total Environ. 488, 115-123. doi: 10.1016/j.scitotenv.2014.04.073

Baptista, G., Kehrig, H. A., Di Beneditto, A. P. M., Hauser-Davis, R. A., Almeida, M. G., Rezende, C. E., et al. (2016). Mercury, selenium and stable isotopes in four small cetaceans from the Southeastern Brazilian coast: influence of feeding strategy. Environ. Pollut. 218, 1298-1307. doi: 10.1016/j.envpol.2016.08.088

Barrett-Lennard, L., Smith, T. G., and Ellis, G. M. (1996). A cetacean biopsy system using lightweight pneumatic darts, and its effect on the behavior of killer whales. Mar. Mamma. Sci. 12, 14-27. doi: 10.1111/j.1748-7692.1996.tb00302.x

Bayas-Rea, R. L. A., Félix, F., and Montufar, R. (2018). Genetic divergence and fine scale population structure of the common bottlenose dolphin (Tursiops truncatus, Montagu) found in the Gulf of Guayaquil, Ecuador. PeerJ 6:e4589. doi: $10.7717 /$ peerj.4589

Betancourt, Ó, Barriga, R., Guimarães, J. R. D., Cueva, E., and Betancourt, S. (2012). "Impacts on environmental health of small-scale gold mining in Ecuador," in Ecohealth Research in Practice. Insight and Innovation in International Development, ed. D. Charron (New York, NY: Springer), 119-130. doi: 10.1007/ 978-1-4614-0517-7_11

Bisi, T. L., Lepoint, G., de Freitas Azevedo, A., Dorneles, P. R., Flach, L., Das, K., et al. (2012). Trophic relationships and mercury biomagnification in Brazilian tropical coastal food webs. Ecol. Indic. 18, 291-302. doi: 10.1016/j.marpolbul. 2013.06.046

Boon, J., Van der Meer, J., Allchin, C., Law, R., Klungsøyr, J., Leonards, P., et al. (1997). Concentration-dependent changes of PCB patterns in fisheating mammals: structural evidence for induction of cytochrome P450. Arch. Environ. Contam. Toxicol. 33, 298-311. doi: 10.1007/s002449900257

Boon, J. P., Lewis, W. E., Tjoen-A-Choy, M. R., Allchin, C. R., Law, R. J., de Boer, J., et al. (2002). Levels of polybrominated diphenyl ether (PBDE) flame retardants in animals representing different trophic levels of the North Sea food web. Environ. Sci. Technol. 36, 4025-4032. doi: 10.1021/es0158298

Borbor-Cordova, M. J., Boyer, E. W., McDowell, W. H., and Hall, C. A. (2006). Nitrogen and phosphorus budgets for a tropical watershed impacted by agricultural land use: guayas. Ecuador. Biogeochemistry 79, 135-161. doi: 10 . 1007/978-1-4020-5517-1_7 
Borrell, A., Bloch, D., and Desportes, G. (1995). Age trends and reproductive transfer of organochlorine compounds in long-finned pilot whales from the Faroe Islands. Environ. Pollut. 88, 283-292. doi: 10.1016/0269-7491(95)93441-2

Bossart, G. (2011). Marine mammals as sentinel species for oceans and human health. Vet. Pathol. 48, 676-690. doi: 10.1177/0300985810388525

Brouwer, A., Reijnders, P., and Koeman, J. (1989). Polychlorinated biphenyl (PCB)contaminated fish induces vitamin $\mathrm{A}$ and thyroid hormone deficiency in the common seal (Phoca vitulina). Aquat. Toxicol. 15, 99-105. doi: 10.1016/0166445x(89)90008-8

Brown, T. M., Macdonald, R. W., Muir, D. C., and Letcher, R. J. (2018). The distribution and trends of persistent organic pollutants and mercury in marine mammals from Canada's Eastern Arctic. Sci. Total Environ. 618, 500-517. doi: 10.1016/j.scitotenv.2017.11.052

Bryan, C. E., Christopher, S. J., Balmer, B. C., and Wells, R. S. (2007). Establishing baseline levels of trace elements in blood and skin of bottlenose dolphins in Sarasota Bay, Florida: implications for non-invasive monitoring. Sci. Total Environ. 388, 325-342. doi: 10.1016/j.scitotenv.2007.07.046

Buckman, A. H., Veldhoen, N., Ellis, G., Ford, J. K., Helbing, C. C., and Ross, P. S. (2011). PCB-associated changes in mRNA expression in killer whales (Orcinus orca) from the NE Pacific Ocean. Environ.Sci. Technol. 45, 10194-10202. doi: $10.1021 / \mathrm{es} 201541 \mathrm{j}$

Cáceres-Saez, I., Goodall, R. N. P., Dellabianca, N. A., Cappozzo, H. L., and Ribeiro Guevara, S. (2015). The skin of Commerson's dolphins (Cephalorhynchus commersonii) as a biomonitor of mercury and selenium in Subantarctic waters. Chemosphere 138, 735-743. doi: 10.1016/j.chemosphere.2015.07.026

Cáceres-Saez, I., Haro, D., Blank, O., Lobo, A. A., Dougnac, C., Arredondo, C., et al. (2018). ). High status of mercury and selenium in false killer whales (Pseudorca crassidens, Owen 1846) stranded on Southern South America: a possible toxicological concern? Chemosphere 199, 637-646. doi: 10.1016/j. chemosphere.2018.02.046

Calle, P., and Alava, J. (2009). "Coastal chemical pollution at continental Ecuador: the case of the Gulf of Guayaquil," in 9th Congress of the Society of Environmental Toxicology and Chemistry (SETAC LA) and the II Peruvian Congress of Ecotoxicology and Environmental Chemistry, (Belgium: SETAC PERU), 1-2.

Calle, P., Alava, J. J., and Montano, M. (2013). ““Assessing chemical pollution in the gulf of guayaquil, ecuador," in 34th Annual Meeting Society of Environmental Toxicology and Chemistry North America (SETAC): Harmonizing Science Across Disciplines, (Nashville, Tennessee).

Calle, P., Monserrate, L., Medina, F., Delgado, M. C., Tirapé, A., Montiel, M., et al. (2018). Mercury assessment, macrobenthos diversity and environmental quality conditions in the Salado Estuary (Gulf of Guayaquil, Ecuador) impacted by anthropogenic influences. Mar. Pollut. Bull. 136, 365-373. doi: 10.1016/j. marpolbul.2018.09.018

Carling, G. T., Diaz, X., Ponce, M., Perez, L., Nasimba, L., Pazmino, E., et al. (2013). Particulate and dissolved trace element concentrations in three southern Ecuador rivers impacted by artisanal gold mining. Water Air Soil Pollut. 224:1415.

Carvajal, R., and Alava, J. (2007). Mangrove wetlands conservation project and the shrimp farming industry in ecuador: lessons learned. World Aquac. 38, 14-17.

Castro, ÎB., Arroyo, M. F., Costa, P. G., and Fillmann, G. (2012). Butyltin compounds and imposex levels in Ecuador. Arch. Environ. Contam. Toxicol. 62, 68-77. doi: 10.1007/s00244-011-9670-2

CEMA (2005). Auditoria Ambiental de Cumplimiento del Sistema de Distribución Eléctrica de la Ciudad de Guayaquil. Informe de Auditoria Preparado para la Corporación de la Administración Eléctrica Temporal de Guayaquil. Guayaquil, EC: Centro de Estudios de Medio Ambiente (CEMA).

Cooke, C. A., Hintelmann, H., Ague, J. J., Burger, R., Biester, H., Sachs, J. P., et al. (2013). Use and legacy of mercury in the Andes. Environ. Sci. Technol. 47, 4181-4188. doi: 10.1021/es3048027

Cullon, D. L., Yunker, M. B., Christensen, J. R., Macdonald, R. W., Whiticar, M. J., Dangerfield, N. J., et al. (2012). Biomagnification of polychlorinated biphenyls in a harbor seal (Phoca vitulina) food web from the strait of Georgia, British Columbia, Canada. Environ. Toxicol. Chem. 31, 2445-2455. doi: 10.1002/etc. 1963

Damseaux, F., Kiszka, J. J., Heithaus, M. R., Scholl, G., Eppe, G., Thomé, J.-P., et al. (2017). Spatial variation in the accumulation of POPs and mercury in bottlenose dolphins of the Lower Florida Keys and the coastal Everglades (South Florida). Environ. Pollut. 220, 577-587. doi: 10.1016/j.envpol.2016.10.005

Desforges, J.-P., Hall, A., McConnell, B., Rosing-Asvid, A., Barber, J. L., Brownlow, A., et al. (2018). Predicting global killer whale population collapse from PCB pollution. Science 361, 1373-1376. doi: 10.1126/science.aat1953

Desforges, J.-P. W., Sonne, C., Levin, M., Siebert, U., De Guise, S., and Dietz, R. (2016). Immunotoxic effects of environmental pollutants in marine mammals. Environ. Int. 86, 126-139. doi: 10.1016/j.envint.2015.10.007

Dietz, R., Sonne, C., Basu, N., Braune, B., O’Hara, T., Letcher, R. J., et al. (2013). What are the toxicological effects of mercury in Arctic biota? Sci. Total Environ. 443, 775-790. doi: 10.1016/j.scitotenv.2012.11.046

Dirtu, A. C., Malarvannan, G., Das, K., Dulau-Drouot, V., Kiszka, J. J., Lepoint, G., et al. (2016). Contrasted accumulation patterns of persistent organic pollutants and mercury in sympatric tropical dolphins from the south-western Indian Ocean. Environ. Res. 146, 263-273. doi: 10.1016/j.envres.2016.01.006

Dorneles, P. R., Lailson-Brito, J., Dirtu, A. C., Weijs, L., Azevedo, A. F., Torres, J. P., et al. (2010). Anthropogenic and naturally-produced organobrominated compounds in marine mammals from Brazil. Environ. Int. 36, 60-67. doi: 10.1016/j.envint.2009.10.001

Durante, C. A., Santos-Neto, E. B., Azevedo, A., Crespo, E. A., and Lailson-Brito, J. (2016). POPs in the South Latin America: bioaccumulation of DDT, PCB, HCB, HCH and Mirex in blubber of common dolphin (Delphinus delphis) and Fraser's dolphin (Lagenodelphis hosei) from Argentina. Sci. Total Environ. 572, 352-360. doi: 10.1016/j.scitotenv.2016.07.176

Fair, P., Romano, T., Reif, J., Schaefer, A., Hulsey, T., Bossart, G., et al. (2013). Association between plasma concentrations of perfluorochemicals (PFCs) and immune and clinical chemistry parameters in bottlenose dolphins (Tursiops truncatus). Environ. Toxicol. Chem. 32, 736-746. doi: 10.1002/etc.2122

Fair, P. A. (2006). Protocols for Conducting Dolphin Capture-Release Health Assessment Studies. Charleston, SC: NOAA/National Ocean Service.

Fair, P. A., Adams, J., Mitchum, G., Hulsey, T. C., Reif, J. S., Houde, M., et al. (2010). Contaminant blubber burdens in Atlantic bottlenose dolphins (Tursiops truncatus) from two southeastern US estuarine areas: concentrations and patterns of PCBs, pesticides, PBDEs, PFCs, and PAHs. Sci. Total Environ. 408, 1577-1597. doi: 10.1016/j.scitotenv.2009.12.021

Fair, P. A., Lee, H.-B., Adams, J., Darling, C., Pacepavicius, G., Alaee, M., et al. (2009). Occurrence of triclosan in plasma of wild Atlantic bottlenose dolphins (Tursiops truncatus) and in their environment. Environ. Pollut. 157, 2248-2254. doi: 10.1016/j.envpol.2009.04.002

Fair, P. A., Mitchum, G., Hulsey, T. C., Adams, J., Zolman, E., McFee, W., et al. (2007). Polybrominated diphenyl ethers (PBDEs) in blubber of free-ranging bottlenose dolphins (Tursiops truncatus) from two southeast Atlantic estuarine areas. Arch. Environ. Contam. Toxicol. 53, 483-494. doi: 10.1007/s00244-0060244-7

Fair, P., Schwacke, L., Zolman, E., McFee, W., and Engleby, L. (2003). “Assessment of contaminant concentrations in tissues of bottlenose dolphins (Tursiops truncatus) in Florida Bay," in Final Report to the Protect Wild Dolphins Grant Program. RFP-PWD-2001 (Harbor: Branch Oceanographic), 18.

Félix, F., Calderón, A., Vintimilla, M., and Bayas-Rea, R. A. (2017). Decreasing population trend in coastal bottlenose dolphin (Tursiops truncatus) from the Gulf of Guayaquil, Ecuador. Aqua. Conserv. Mar. Freshw. Ecosyst. 27, 856-866. doi: 10.1002 /aqc. 2763

Fernández-Cadena, J. C., Andrade, S., Silva-Coello, C., and De la Iglesia, R. (2014). Heavy metal concentration in mangrove surface sediments from the north-west coast of South America. Mar. Pollut. Bull 82, 221-226. doi: 10.1016/j.marpolbul. 2014.03.016

Fort, J., Lacoue-Labarthe, T., Nguyen, H., Boué, A., Spitz, J., and Bustamante, P. (2015). Mercury in wintering seabirds, an aggravating factor to winter wrecks? Sci. Total Environ. 527, 448-454. doi: 10.1016/j.scitotenv.2015.05.018

Frouin, H., Lebeuf, M., Hammill, M., Masson, S., and Fournier, M. (2010). Effects of individual polybrominated diphenyl ether (PBDE) congeners on harbour seal immune cells in vitro. Mar. Pollut. Bull. 60, 291-298. doi: 10.1016/j.marpolbul. 2009.09.006

Fruet, P. F., Dalla Rosa, L., Genoves, R. C., Valiati, V. H., de Freitas, T. R., and Möller, L. M. (2017). Biopsy darting of common bottlenose dolphins (Tursiops truncatus) in southern Brazil: evaluating effectiveness, short-term responses and wound healing. Latin Am. J. Aquat. Mamm. 11, 121-132. 
Galligan, T. M., Balmer, B. C., Schwacke, L. H., Bolton, J. L., Quigley, B. M., Rosel, P. E., et al. (2019). Examining the relationships between blubber steroid hormones and persistent organic pollutants in common bottlenose dolphins. Environ. Pollut. 249, 982-991. doi: 10.1016/j.envpol.2019.03.083

Gerpe, M., Rodríguez, D., Moreno, V. J., Bastida, R. O., and Moreno, J. D. (2002). Accumulation of heavy metals in the franciscana (Pontoporia blainvillei) from Buenos Aires Province. Argentina. Latin Am. J. Aquat. Mamm. 1, 95-106.

Gobas, F. A. P. C., and Arnot, J. A. (2010). Food web bioaccumulation model for polychlorinated biphenyls in San Francisco Bay, California, USA. Environ. Toxicol. Chem. 29, 1385-1395. doi: 10.1002/etc.164

Gui, D., Yu, R., He, X., Tu, Q., Chen, L., and Wu, Y. (2014). Bioaccumulation and biomagnification of persistent organic pollutants in Indo-Pacific humpback dolphins (Sousa chinensis) from the Pearl River Estuary, China. Chemosphere 114, 106-113. doi: 10.1016/j.chemosphere.2014.04.028

Guise, S. D. (1998). Effects of in vitro exposure of beluga whale leukocytes to selected organochlorines. J. Toxicol. Environ. Health Part A 55, 479-493. doi: $10.1080 / 009841098158287$

Hall, A. J., Kalantzi, O. I., and Thomas, G. O. (2003). Polybrominated diphenyl ethers (PBDEs) in grey seals during their first year of life-are they thyroid hormone endocrine disrupters? Environ. Pollut. 126, 29-37. doi: 10.1016/ s0269-7491(03)00149-0

Hall, A. J., McConnell, B. J., Rowles, T. K., Aguilar, A., Borrell, A., Schwacke, L., et al. (2005). Individual-based model framework to assess population consequences of polychlorinated biphenyl exposure in bottlenose dolphins. Environ. Health Perspect. 114, 60-64. doi: 10.1289/ehp.8053

Hall, A. J., and Thomas, G. O. (2007). Polychlorinated biphenyls, DDT, polybrominated diphenyl ethers, and organic pesticides in United Kingdom harbor seals (Phoca vitulina)-mixed exposures and thyroid homeostasis. Environ. Toxicol. Chem. Int J. 26, 851-861.

Hallgren, S., and Darnerud, P. O. (2002). Polybrominated diphenyl ethers (PBDEs), polychlorinated biphenyls (PCBs) and chlorinated paraffins (CPs) in ratstesting interactions and mechanisms for thyroid hormone effects. Toxicology 177, 227-243. doi: 10.1016/s0300-483x(02)00222-6

Hickie, B. E., Cadieux, M. A., Riehl, K. N., Bossart, G. D., Alava, J. J., and Fair, P. A. (2013). Modeling PCB-bioaccumulation in the bottlenose dolphin (Tursiops truncatus): estimating a dietary threshold concentration. Environ. Sci. Technol. 47, 12314-12324. doi: 10.1021/es403166b

Hickie, B. E., Ross, P. S., Macdonald, R. W., and Ford, J. K. (2007). Killer whales (Orcinus orca) face protracted health risks associated with lifetime exposure to PCBs. Environ. Sci Technol. 41, 6613-6619. doi: 10.1021/es0702519

Hites, R. A. (2004). Polybrominated diphenyl ethers in the environment and in people: a meta-analysis of concentrations. Environ. Sci. Technol. 38, 945-956. doi: $10.1021 /$ es035082g

Inocar (2008). Estudio de Impacto Ambiental Para los Trabajos de Dragado Permanente del Canal de Acceso al Puerto Marítimo de la Ciudad de GUAYAQUIL. Guayaquil: Instituto Oceanográfico de la Armada.

Iwata, H., Tanabe, S., Sakai, N., Nishimura, A., and Tatsukawa, R. (1994). Geographical distribution of persistent organochlorines in air, water and sediments from Asia and Oceania, and their implications for global redistribution from lower latitudes. Environ. Pollut. 85, 15-33. doi: 10.1016/ 0269-7491(94)90234-8

Iwata, H., Tanabe, S., Sakai, N., and Tatsukawa, R. (1993). Distribution of persistent organochlorines in the oceanic air and surface seawater and the role of ocean on their global transport and fate. Environ. Sci. Technol. 27, 1080-1098. doi: 10.1021/es00043a007

Jefferson, T. A., and Hung, S. K. (2008). Effects of biopsy sampling on Indo-Pacific humpback dolphins (Sousa chinensis) in a polluted coastal environment. Aquat. Mamm. 34:310. doi: 10.1578/am.34.3.2008.310

Jepson, P. D., Deaville, R., Barber, J. L., Aguilar, À, Borrell, A., Murphy, S., et al. (2016). PCB pollution continues to impact populations of orcas and other dolphins in European waters. Sci. Rep. 6:18573. doi: 10.1038/srep18573

Jiménez, P., and Alava, J. J. (2014). "Population ecology and anthropogenic stressors of the coastal bottlenose dolphin (Tursiops truncatus) in the El morro mangrove and wildlife refuge, guayaquil gulf, ecuador: towards conservation and management actions," in Dolphins: Ecology, Behavior and Conservation Strategies, Series: Marine Biology, (Hauppauge, NY: Nova Science Publishers), $129-163$.
Jiménez, P., Alava, J. J., Castro, C., Denkinger, J., Haase, B., Utreras, V., et al. (2011). Delfín nariz de botella, Tursiops truncatus. Libro rojo de los Mamíferos de Ecuador 2, 239-240.

Jiménez, P., Alava, J. J., Castro, C., Samaniego, J., and Fair, P. (2018). Stranding of small cetaceans with missing fins raises concerns on cetacean conservation in Ecuador: bycatch or targeted fisheries. Int. Jo. Fisher. Sci. Res. 2, 1-4.

Jiménez, P. J., and Alava, J. J. (2015). Strand-feeding by coastal bottlenose dolphins (Tursiops truncatus) in the Gulf of Guayaquil, Ecuador. Latin Am. J. Aquat. Mamm. 10, 33-37. doi: 10.3354/dao03356

Jonsson, S., Andersson, A., Nilsson, M. B., Skyllberg, U., Lundberg, E., Schaefer, J. K., et al. (2017). Terrestrial discharges mediate trophic shifts and enhance methylmercury accumulation in estuarine biota. Sci. Adv. 3:e1601239. doi: 10. 1126/sciadv.1601239

Kajiwara, N., Kamikawa, S., Amano, M., Hayano, A., Yamada, T. K., Miyazaki, N., et al. (2008). Polybrominated diphenyl ethers (PBDEs) and organochlorines in melon-headed whales, Peponocephala electra, mass stranded along the Japanese coasts: maternal transfer and temporal trend. Environ. Pollut. 156, 106-114. doi: 10.1016/j.envpol.2007.12.034

Kannan, K., Blankenship, A., Jones, P., and Giesy, J. (2000). Toxicity reference values for the toxic effects of polychlorinated biphenyls to aquatic mammals. Hum. Ecol. Risk Assess. 6, 181-201. doi: 10.1080/10807030091124491

Kannan, K., Ramu, K., Kajiwara, N., Sinha, R., and Tanabe, S. (2005). Organochlorine pesticides, polychlorinated biphenyls, and polybrominated diphenyl ethers in Irrawaddy dolphins from India. Arch. Environ. Contam. Toxicol. 49, 415-420. doi: 10.1007/s00244-005-7078-6

Kehrig, H. A., Baptista, G., Di Beneditto, A. P. M., Almeida, M. G., Rezende, C. E., Siciliano, S., et al. (2017). Biomagnificación de mercurio en la cadena trófica del Delfín Moteado del Atlántico (Stenella frontalis), usando el isótopo estable de nitrógeno como marcador ecológico. Rev. Biol.Mar.y Oceanogr. 52, 233-244. doi: 10.4067/s0718-19572017000200004

Kehrig, H. A., Hauser-Davis, R. A., Seixas, T. G., Pinheiro, A. B., and Di Beneditto, A. P. M. (2016). Mercury species, selenium, metallothioneins and glutathione in two dolphins from the southeastern Brazilian coast: mercury detoxification and physiological differences in diving capacity. Environ. Pollut. 213, 785-792. doi: 10.1016/j.envpol.2016.03.041

Kehrig, H. A., Seixas, T. G., Malm, O., Di Beneditto, A. P. M., and Rezende, C. E. (2013). Mercury and selenium biomagnification in a Brazilian coastal food web using nitrogen stable isotope analysis: a case study in an area under the influence of the Paraiba do Sul River plume. Mar. Pollut. Bull. 75, 283-290. doi: 10.1016/j.marpolbul.2013.06.046

Kelce, W. R., Stone, C. R., Laws, S. C., Gray, L. E., Kemppainen, J. A., and Wilson, E. M. (1995). Persistent DDT metabolite p, p'-DDE is a potent androgen receptor antagonist. Nature 375:581. doi: 10.1038/375581a0

Kelly, B. C., Ikonomou, M. G., Blair, J. D., and Gobas, F. A. (2008). Bioaccumulation behaviour of polybrominated diphenyl ethers (PBDEs) in a Canadian Arctic marine food web. Sci. Total Enviro. 401, 60-72. doi: 10.1016/j.scitotenv.2008. 03.045

Kelly, B. C., Ikonomou, M. G., Blair, J. D., Morin, A. E., and Gobas, F. A. (2007). Food web-specific biomagnification of persistent organic pollutants. Science 317, 236-239. doi: 10.1126/science. 1138275

Kelly, B. C., Ikonomou, M. G., Blair, J. D., Surridge, B., Hoover, D., Grace, R., et al. (2009). Perfluoroalkyl contaminants in an Arctic marine food web: trophic magnification and wildlife exposure. Environ. Sci. Technol. 43, 4037-4043. doi: 10.1021/es9003894

Kershaw, J., and Hall, A. (2019). Mercury in cetaceans: exposure, bioaccumulation and toxicity. Sci. Total Environ. 694:133683. doi: 10.1016/j.scitotenv.2019. 133683

Kiszka, J., Simon-Bouhet, B., Charlier, F., Pusineri, C., and Ridoux, V. (2010). Individual and Group Behavioural Reactions of Small Delphinids to Remote Biopsy Sampling. Rome: Food And Agriculture Organization.

Krützen, M., Barré, L. M., Möller, L. M., Heithaus, M. R., Simms, C., and Sherwin, W. B. (2002). A biopsy system for small cetaceans: darting success and wound healing in Tursiops spp. Mar. Mamm. Sci. 18, 863-878. doi: 10.1111/j.17487692.2002.tb01078.x

Kucklick, J., Schwacke, L., Wells, R., Hohn, A., Guichard, A., Yordy, J., et al. (2011). Bottlenose dolphins as indicators of persistent organic pollutants in the western North Atlantic Ocean and northern Gulf of Mexico. Environ. Sci. Technol. 45, 4270-4277. doi: 10.1021/es1042244 
Lahvis, G. P., Wells, R. S., Kuehl, D. W., Stewart, J. L., Rhinehart, H. L., and Via, C. S. (1995). Decreased lymphocyte responses in free-ranging bottlenose dolphins (Tursiops truncatus) are associated with increased concentrations of PCBs and DDT in peripheral blood. Environ. Health Perspect 103, 67-72. doi: 10.1289/ehp.95103s467

Lavandier, R., Arêas, J., Dias, P. S., Taniguchi, S., Montone, R., de Moura, J. F., et al. (2015). An assessment of PCB and PBDE contamination in two tropical dolphin species from the Southeastern Brazilian coast. Mar. Pollut. Bull. 101, 947-953. doi: 10.1016/j.marpolbul.2015.10.039

Lavandier, R., Arêas, J., Quinete, N., de Moura, J. F., Taniguchi, S., Montone, R., et al. (2016). PCB and PBDE levels in a highly threatened dolphin species from the Southeastern Brazilian coast. Environ. Pollut. 208, 442-449. doi: 10.1016/j. envpol.2015.10.013

Lavandier, R., Arêas, J., Quinete, N., de Moura, J. F., Taniguchi, S., Montone, R., et al. (2019). PCB and PBDE contamination in Tursiops truncatus and Stenella frontalis, two data-deficient threatened dolphin species from the Brazilian coast. Ecotoxicol. Environ. Saf. 167, 485-493. doi: 10.1016/j.ecoenv.2018.10.045

Lavoie, R. A., Jardine, T. D., Chumchal, M. M., Kidd, K. A., and Campbell, L. M. (2013). Biomagnification of mercury in aquatic food webs: a worldwide meta-analysis. Environ. Sci. Technol. 47, 13385-13394. doi: 10.1021/es403103t

Letcher, R. J., Bustnes, J. O., Dietz, R., Jenssen, B. M., Jørgensen, E. H., Sonne, C., et al. (2010). Exposure and effects assessment of persistent organohalogen contaminants in arctic wildlife and fish. Sci. Total Environ. 408, 2995-3043. doi: 10.1016/j.scitotenv.2009.10.038

Litz, J. A., Garrison, L. P., Fieber, L. A., Martinez, A., Contillo, J. P., and Kucklick, J. R. (2007). Fine-scale spatial variation of persistent organic pollutants in bottlenose dolphins (Tursiops truncatus) in Biscayne Bay. Florida. Environ. Sci. Technol. 41, 7222-7228. doi: 10.1021/es070440r

MAE (2004). Inventario de Plaguicidas COPs en el Ecuador. Informe Técnico Final. Proyecto GEF/2732-02-4456. Quito, EC: Ministerio del Ambiente del Ecuador (MAE), 154.

MAE (2006). Plan Nacional de Implementación para la Gestión de los Contaminantes Orgánicos Persistentes en el Ecuador. GEF/2732-02-4456. Quito, EC: Ministerio del Ambiente del Ecuador (MAE), 144.

Maruya, K. A., Schlenk, D., Anderson, P. D., Denslow, N. D., Drewes, J. E., Olivieri, A. W., et al. (2014). An adaptive, comprehensive monitoring strategy for chemicals of emerging concern (CECs) in California's aquatic ecosystems. Integr. Environ. Assess. Manag. 10, 69-77. doi: 10.1002/ieam.1483

Meerts, I., Letcher, R. J., Hoving, S., Marsh, G., Bergman, A., Lemmen, J. G., et al. (2001). In vitro estrogenicity of polybrominated diphenyl ethers, hydroxylated PDBEs, and polybrominated bisphenol A compounds. Environ. Health Perspect. 109, 399-407. doi: 10.1289/ehp.01109399

Montaño, M., and Resabala, C. (2005). Pesticidas en sedimentos, aguas, y organismos de la Cuenca del Rio Taura. Revista de Ciencias Naturales $y$ Ambientales 1, 93-98.

Mos, L., Cameron, M., Jeffries, S. J., Koop, B. F., and Ross, P. S. (2010). Risk-based analysis of polychlorinated biphenyl toxicity in harbor seals. Integr. Environ. Assess. Manag. 6, 631-640. doi: 10.1002/ieam.104

Muñoz-Arnanz, J., Chirife, A., Vernazzani, B. G., Cabrera, E., Sironi, M., Millán, J., et al. (2019). First assessment of persistent organic pollutant contamination in blubber of Chilean blue whales from Isla de Chiloé, southern Chile. Sci. Total Environ. 650, 1521-1528. doi: 10.1016/j.scitotenv.2018.09.070

Nei, M. (1987). Molecular Evolutionary Genetics. New York, NY: Columbia University Press.

Noël, M., Dangerfield, N., Hourston, R. A. S., Belzer, W., Shaw, P., Yunker, M. B., et al. (2009). Do trans-Pacific air masses deliver PBDEs to coastal British Columbia. Canada? Environ. Pollut. 157, 3404-3412. doi: 10.1016/j.envpol. 2009.06.025

Palumbi, S. (1996). "Nucleic acids II: the polymerase chain reaction," in 'Molecular Systematics', eds D. M. Hillis, C. Moritz, and B. K. Mable, (Sunderland, MA: Sinauer Associates), 205-247.

Parsons, K., Durban, J., and Claridge, D. (2003). Comparing two alternative methods for sampling small cetaceans for molecular analysis. Mar. Mamm. Sci. 19, 224-231. doi: 10.1111/j.1748-7692.2003.tb01104.x

Peñín, I., Levin, M., Acevedo-Whitehouse, K., Jasperse, L., Gebhard, E., Gulland, F., et al. (2018). Effects of polychlorinated biphenyls (PCB) on California sea lion (Zalophus californianus) lymphocyte functions upon in vitro exposure. Environ. Res. 167, 708-717. doi: 10.1016/j.envres.2018.08.028
Pulster, E. L., and Maruya, K. A. (2008). Geographic specificity of Aroclor 1268 in bottlenose dolphins (Tursiops truncatus) frequenting the Turtle/ Brunswick River Estuary. Georgia (USA). Sci. Total Environ. 393, 367-375. doi: 10.1016/j. scitotenv.2007.12.031

Ramón-Jibaja, C. A. (2018). "Estudio de Impacto Ambiental del Proyecto Construcción, Operación, Mantenimiento, Cierre y Abandono del Dragado de Profundización y Mantenimiento del Canal de Acceso a las Terminales Portuarias Marítimas y Fluviales, Públicas y Privadas De Guayaquil," in Registro No : MAE-SUIA-0516-CI, (Guayaquil: M.I. Municipalidad de Guayaquil).

Rayne, S., Ikonomou, M. G., Ross, P. S., Ellis, G. M., and Barrett-Lennard, L. G. (2004). PBDEs, PBBs, and PCNs in three communities of free-ranging killer whales (Orcinus orca) from the northeastern Pacific Ocean. Environ. Sci. Technol. 38, 4293-4299. doi: 10.1021/es0495011

Reif, J., Fair, P., Adams, J., Joseph, B., Kilpatrick, D., Sanchez, R., et al. (2008). Health status of Atlantic bottlenose dolphins (Tursiops truncatus) from the Indian River Lagoon. FL and Charleston, SC. J. Am. Vet. Med. Assoc. 233, 299-307.

Reif, J. S., Schaefer, A. M., Bossart, G. D., and Fair, P. A. (2017). Health and environmental risk assessment project for bottlenose dolphins Tursiops truncatus from the southeastern USA. II. Environmental aspects. Dis. Aquat. Org. 125, 155-166. doi: 10.3354/dao03143

Rosel, P. E. (2003). PCR-based sex determination in Odontocete cetaceans. Conserv. Genet. 4, 647-649.

Ross, P., De Swart, R., Addison, R., Van Loveren, H., Vos, J., and Osterhaus, A. (1996). Contaminant-induced immunotoxicity in harbour seals: wildlife at risk? Toxicology 112, 157-169. doi: 10.1016/0300-483x(96)03396-3

Ross, P. S., De Swart, R. L., Van Loveren, H., Osterhaus, A. D., and Vos, J. G. (1996). The immunotoxicity of environmental contaminants to marine wildlife: a review. Annu. Rev. Fish Dis. 6, 151-165. doi: 10.1016/s0959-8030(96) 90011-3

Ross, P. S., De Swart, R. L., Reijnders, P., Van Loveren, H., Vos, J. G., and Osterhaus, A. (1995). Contaminant-related suppression of delayed-type hypersensitivity and antibody responses in harbor seals fed herring from the Baltic Sea. Environ. Health Perspect. 103, 162-167. doi: 10.1289/ehp.95103162

Ross, P. S., Ellis, G., Ikonomou, M., Barrett-Lennard, L., and Addison, R. (2000). High PCB concentrations in free-ranging Pacific killer whales, Orcinus orca: effects of age, sex and dietary preference. Mar. Pollut. Bull. 40, 504-515. doi: 10.1007/s10646-014-1300-0

Sandheinrich, M., and Wiener, J. (2011). Methylmercury in freshwater fish: recent advances in assessing toxicity of environmentally relevant exposures. Environ. Contam. Biota 2, 169-190. doi: 10.1201/b10598-6

Santos-Neto, E. B., Azevedo-Silva, C. E., Bisi, T. L., Santos, J., Meirelles, A. C. O., Carvalho, V. L., et al. (2014). Organochlorine concentrations (PCBs, DDTs, HCHs, HCB and MIREX) in delphinids stranded at the northeastern Brazil. Sci. Total Environ. 472, 194-203. doi: 10.1016/j.scitotenv.2013.10.117

Scheuhammer, A., Braune, B., Chan, H. M., Frouin, H., Krey, A., Letcher, R., et al. (2015). Recent progress on our understanding of the biological effects of mercury in fish and wildlife in the Canadian Arctic. Sci. Total Environ. 509, 91-103. doi: 10.1016/j.scitotenv.2014.05.142

Scheuhammer, A. M., Meyer, M. W., Sandheinrich, M. B., and Murray, M. W. (2007). Effects of environmental methylmercury on the health of wild birds, mammals, and fish. AMBIOJ. Hum. Environ. 36, 12-20.

Stavros, H., Bossart, G. D., Hulsey, T. C., and Fair, P. A. (2008). Trace element concentrations in blood of free-ranging bottlenose dolphins (Tursiops truncatus): influence of age, sex and location. Mar. Pollut. Bull. 56, 371-379. doi: 10.1016/j.marpolbul.2007.10.030

Stavros, H.-C. W., Bossart, G. D., Hulsey, T. C., and Fair, P. A. (2007). Trace element concentrations in skin of free-ranging bottlenose dolphins (Tursiops truncatus) from the southeast Atlantic coast. Sci. Total Environ. 388, 300-315. doi: 10.1016/j.scitotenv.2007.07.030

Tabuchi, M., Veldhoen, N., Dangerfield, N., Jeffries, S., Helbing, C. C., and Ross, P. S. (2006). PCB-related alteration of thyroid hormones and thyroid hormone receptor gene expression in free-ranging harbor seals (Phoca vitulina). Environ. Health Perspect. 114, 1024-1031. doi: 10.1289/ehp.8661

Tanabe, S., Madhusree, B., Öztürk, A. A., Tatsukawa, R., Miyazaki, N., Özdamar, E., et al. (1997). Persistent organochlorine residues in harbour porpoise (Phocoena phocoena) from the Black Sea. Mar. Pollut. Bull. 34, 338-347. doi: 10.1016/ s0025-326x(96)00081-1 
Tanabe, S., Watanabe, S., Kan, H., and Tatsukawa, R. (1988). Capacity and mode of PCB metabolism in small cetaceans. Mar. Mamm. Sci. 4, 103-124. doi: 10.1111/j.1748-7692.1988.tb00191.x

Tarras-Wahlberg, N. H., Flachier, A., Fredriksson, G., Lane, S., Lundberg, B., and Sangfors, O. (2000). Environmental impact of small-scale and artisanal gold mining in southern Ecuador. AMBIO J. Hum. Environ. 29, 484-492.

Tezanos-Pinto, G., and Baker, C. (2012). Short-term reactions and long-term responses of bottlenose dolphins (Tursiops truncatus) to remote biopsy sampling. N. Z. J. Mar. Freshw. Res. 46, 13-29. doi: 10.1080/00288330.2011. 583256

Twilley, R., Cárdenas, W., Rivera-Monroy, V., Espinoza, J., Suescum, R., Armijos, M., et al. (2001). "The Gulf of Guayaquil and the Guayas river estuary, Ecuador," in Coastal marine ecosystems of Latin America. Berlin: Springer, 245-263.

UNEP (2002). United Nations Environmental Programme: Protecting the environment from Persistent Organic Pollutants and other persistent toxic substances. Geneva: Switzerland". UNEP/GEF.

UNEP (2016). Nations Environmental Programme: Minamata Convention on Mercury. Available: www.mercuryconvention.org/Convention. (Accessed 0910-2019).

Van den Berg, M., Birnbaum, L. S., Denison, M., De Vito, M., Farland, W., Feeley, M., et al. (2006). The 2005 World Health Organization Reevaluation of Human and Mammalian Toxic Equivalency Factors for Dioxins and Dioxin-Like Compounds. Toxico. Sci. 93, 223-241. doi: 10.1093/toxsci/kf 1055

Wagemann, R., Trebacz, E., Boila, G., and Lockhart, W. L. (1998). Methylmercury and total mercury in tissues of arctic marine mammals. Sci. Total Environ. 218, 19-31. doi: 10.1016/s0048-9697(98)00192-2

Weller, D. W., Cockcroft, V. G., Würsig, B., Lynn, S. K., and Fertl, D. (1997). Behavioral responses of bottlenose dolphins to remote biopsy sampling and observations of surgical biopsy wound healing. Aquat. Mamm. 23, 49-58.

Wells, R. S., Rhinehart, H. L., Hansen, L. J., Sweeney, J. C., Townsend, F. I., Stone, R., et al. (2004). Bottlenose dolphins as marine ecosystem sentinels: developing a health monitoring system. EcoHealth 1, 246-254.

Wells, R. S., Tornero, V., Borrell, A., Aguilar, A., Rowles, T. K., Rhinehart, H. L., et al. (2005). Integrating life-history and reproductive success data to examine potential relationships with organochlorine compounds for bottlenose dolphins (Tursiops truncatus) in Sarasota Bay. Florida. Sci. Total Environ. 349, 106-119. doi: 10.1016/j.scitotenv.2005.01.010

Wenzel, F., Nicolas, J., Larsen, F., and Pace, R. M. (2010). Northeast Fisheries Science Center Cetacean Biopsy Training Manual. US Dept Commerce, Northeast Fisheries Science Center Reference Document 10-11. Woods Hole, MA: National Marine Fisheries Service, 18.

Whitehead, H., Gordon, J., Mathews, E. A., and Richard, K. R. (1990). Obtaining skin samples from living sperm whales. Mar. Mamm. Sci. 6, 316-326. doi: 10.1111/j.1748-7692.1990.tb00361.x
Wiener, J. G., Bodaly, R., Brown, S. S., Lucotte, M., Newman, M. C., Porcella, D. B., et al. (2007). "Monitoring and evaluating trends in methylmercury accumulation in aquatic biota," in Ecosystem Responses to Mercury Contamination, (Boca Raton, FL: CRC Press), 98-133.

Wilkening, K. E., Barrie, L. A., and Engle, M. (2000). Trans-Pacific air pollution. Science 290, 65-67. doi: 10.1126/science.290.5489.65

Wolkers, H., Van Bavel, B., Derocher, A. E., Wiig, Ø, Kovacs, K. M., Lydersen, C., et al. (2004). Congener-specific accumulation and food chain transfer of polybrominated diphenyl ethers in two Arctic food chains. Environ. Sci. Technol. 38, 1667-1674. doi: 10.1021/es030448a

Woshner, V., Knott, K., Wells, R., Willetto, C., Swor, R., and O’Hara, T. (2008). Mercury and selenium in blood and epidermis of bottlenose dolphins (Tursiops truncatus) from Sarasota Bay, FL: interaction and relevance to life history and hematologic parameters. EcoHealth 5, 360-370. doi: 10.1007/s10393-0080164-2

Ylitalo, G. M., Matkin, C. O., Buzitis, J., Krahn, M. M., Jones, L. L., Rowles, T., et al. (2001). Influence of life-history parameters on organochlorine concentrations in free-ranging killer whales (Orcinus orca) from Prince William Sound. AK. Sci. Total Environ. 281, 183-203. doi: 10.1016/s0048-9697(01)00846-4

Ylitalo, G. M., Stein, J. E., Hom, T., Johnson, L. L., Tilbury, K. L., Hall, A. J., et al. (2005). The role of organochlorines in cancer-associated mortality in California sea lions (Zalophus californianus). Mar. Pollut. Bull. 50, 30-39. doi: 10.1016/j.marpolbul.2004.08.005

Yogui, G., and Sericano, J. (2009). Polybrominated diphenyl ether flame retardants in the US marine environment: a review. Environ. Int. 35, 655-666. doi: 10. 1016/j.envint.2008.11.001

Yordy, J. E., Wells, R. S., Balmer, B. C., Schwacke, L. H., Rowles, T. K., and Kucklick, J. R. (2010). Partitioning of persistent organic pollutants between blubber and blood of wild bottlenose dolphins: implications for biomonitoring and health. Environ. Sci. Technol. 44, 4789-4795. doi: 10.1021/es1004158

Zanuttini, C., Gally, F., Scholl, G., Thomé, J.-P., Eppe, G., and Das, K. (2019). High pollutant exposure level of the largest European community of bottlenose dolphins in the English Channel. Sci. Rep. 9, 1-10. doi: 10.1038/s41598-01948485-7

Conflict of Interest: The authors declare that the research was conducted in the absence of any commercial or financial relationships that could be construed as a potential conflict of interest.

Copyright (c) 2020 Alava, Calle, Tirapé, Biedenbach, Alvarado Cadena, Maruya, Lao, Aguirre, Jiménez, Domínguez, Bossart and Fair. This is an open-access article distributed under the terms of the Creative Commons Attribution License (CC BY). The use, distribution or reproduction in other forums is permitted, provided the original author(s) and the copyright owner(s) are credited and that the original publication in this journal is cited, in accordance with accepted academic practice. No use, distribution or reproduction is permitted which does not comply with these terms. 